\title{
SUBSÍDIOS PARA UM PROGRAMA DE MANEJO DA RESISTÊNCIA DE Aphis gossypii GLOVER, 1877 A INSETICIDAS NA CULTURA DO ALGODÃO
}

\author{
ROBERTO HIROYUKI KONNO
}

Tese apresentada à Escola Superior de Agricultura
“Luiz de Queiroz”, Universidade de São Paulo,
para obtenção do título de Doutor em Ciências,
Área de Concentração: Entomologia.

P I R A C I C A B A

Estado de São Paulo - Brasil

Janeiro - 2005 


\section{SUBSÍDIOS PARA UM PROGRAMA DE MANEJO DA RESISTÊNCIA DE Aphis gossypii GLOVER, 1877 A INSETICIDAS NA CULTURA DO ALGODÃO}

\section{ROBERTO HIROYUKI KONNO}

Engenheiro Agrônomo

Orientador: Prof. Dr. CELSO OMOTO

Tese apresentada à Escola Superior de Agricultura

“Luiz de Queiroz”, Universidade de São Paulo, para obtenção do título de Doutor em Ciências, Área de Concentração: Entomologia.

P I R A C I C A B A

Estado de São Paulo - Brasil

Janeiro - 2005 
Dados Internacionais de Catalogação na Publicação (CIP) DIVISÃO DE BIBLIOTECA E DOCUMENTAÇÃO - ESALQ/USP

Konno, Roberto Hiroyuki

Subsídios para um programa de manejo da resistência de Aphis gossypii Glover, 1877 a inseticidas na cultura do algodão / Roberto Huroyuki Konno. - - Piracicaba, 2005.

$72 \mathrm{p}$

Tese (Doutorado) - - Escola Superior de Agricultura Luiz de Queiroz, 2005.

Bibliografia.

1. Algodão 2. Inseticidas 3. Pulgão 5. Resistência ao pesticida I. Título

CDD 633.51

"Permitida a cópia total ou parcial deste documento, desde que citada a fonte - 0 autor" 
Aos meus pais

Maria e Takayuki pelo amor, dedicação e exemplo

Dedico...

À minha irmã Angela e

aos meus tios Setuko e Antonio pelo apoio 


\section{AGRADECIMENTOS}

Ao Prof. Dr. Celso Omoto pela confiança, incentivo e orientação na realização deste trabalho.

Aos professores do Programa de Pós-graduação em Entomologia da USP/ESALQ, pelos ensinamentos transmitidos durante o curso.

Aos professores Dr. Sílvio Sandoval Zocchi e Dr. Hilton Thadeu Zarate Couto pela colaboração nas análises estatísticas dos dados.

Ao Conselho Nacional de Desenvolvimento Científico e Tecnológico (CNPq) pela concessão da bolsa de estudo.

À FMC do Brasil Indústria e Comércio Ltda., em especial à Eng. Agr. Maria de Lourdes S. Faustino, pelo apoio à pesquisa.

Aos eng. agrônomos e colegas de curso Cláudio R. Franco, Everaldo B. Alves, Fernando J. Campos, Marcelo Poletti e Samuel Martinelli pela amizade e colaboração.

Aos colegas do Programa de Pós-graduação em Entomologia pela amizade e companheirismo.

À Bibliotecária Silvia Zinsly pelas correções das referências bibliográficas. 


\section{SUMÁRIO}

Página

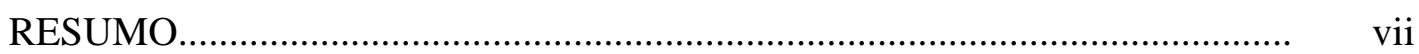

SUMMARY .................................................... ix

1 INTRODUÇÃO

2 REVISÃO DE LITERATURA........................................................... 4

$2.1 \quad$ Resistência de Aphis gossypii a inseticidas............................................. 4

2.2 Fatores que afetam a evolução de resistência de Aphis gossypii a

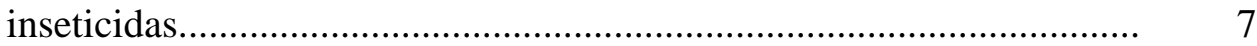

2.2.1 Fatores genéticos................................................................................. 8

2.2.2 Fatores bioecológicos................................................................... 9

2.2.3 Fatores operacionais...................................................................... 10

3 MATERIAL E MÉTODOS............................................................... 13

3.1 Criação de Aphis gossypii em laboratório............................................... 13

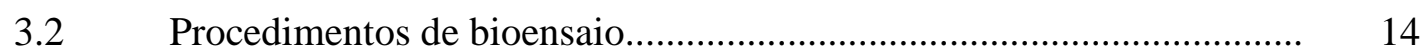

3.3 Caracterização da linha-básica de suscetibilidade de Aphis gossypii a

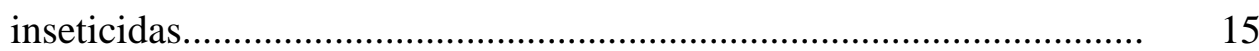

3.4 Monitoramento da suscetibilidade de Aphis gossypii a

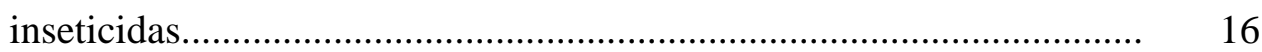

3.5 Isolamento e caracterização da resistência de Aphis gossypii ao inseticida carbosulfam...................................................................... 22

3.6 Relações de resistência cruzada entre carbosulfam e os inseticidas tiametoxam e endosulfam. 
3.7 Custo adaptativo associado à resistência de Aphis gossypii ao inseticida carbosulfam.

3.7.1 Dinâmica da resistência de Aphis gossypii ao inseticida carbosulfam em condições de laboratório.

3.7.2 Biologia das linhagens de Aphis gossypii suscetível e resistente ao inseticida carbosulfam em condições de laboratório.

3.8 Efeito de mistura de inseticidas e dos produtos isolados sobre as linhagens de Aphis gossypii suscetível e resistente ao inseticida carbosulfam

4 RESULTADOS E DISCUSSÃO

4.1 Caracterização da linha-básica de suscetibilidade de Aphis gossypii a inseticidas.

4.2 Monitoramento da suscetibilidade de Aphis gossypii a inseticidas

4.3 Isolamento e caracterização da resistência de Aphis gossypii ao inseticida carbosulfam.

4.4 Relações de resistência cruzada entre carbosulfam e os inseticidas tiametoxam e endosulfam.

4.5 Dinâmica da resistência de Aphis gossypii ao inseticida carbosulfam em condições de laboratório.

4.6 Biologia das linhagens de Aphis gossypii suscetível e resistente ao inseticida carbosulfam em condições de laboratório.

4.7 Efeito de mistura de inseticidas e dos produtos isolados sobre as linhagens de Aphis gossypii suscetível e resistente ao inseticida carbosulfam 


\title{
SUBSÍDIOS PARA UM PROGRAMA DE MANEJO DA RESISTÊNCIA DE Aphis gossypii GLOVER, 1877 A INSETICIDAS NA CULTURA DO ALGODÃO
}

\author{
Autor: ROBERTO HIROYUKI KONNO \\ Orientador: Prof. Dr. CELSO OMOTO
}

\section{RESUMO}

O objetivo do presente trabalho foi o de coletar informações básicas para a implementação de um programa de manejo da resistência de Aphis gossypii Glover, 1877 a inseticidas na cultura do algodão. Para tanto, foram caracterizadas as linhas-básicas de suscetibilidade de A. gossypii aos inseticidas carbosulfam, tiametoxam e endosulfam por meio de um bioensaio de contato residual. Posteriormente, foi realizado um monitoramento da suscetibilidade a esses inseticidas em populações de A. gossypii que foram coletadas nas regiões de Acreúna-GO, Ituverava-SP, Rondonópolis-MT e Unai-MG nas safras de algodão de 2001/2002 a 2003/2004. Em cada safra, as coletas de pulgões foram realizadas no início, meio e final do ciclo da cultura. Não foram observadas diferenças significativas na suscetibilidade de populações de A. gossypii para tiametoxam e endosulfam. Por outro lado, houve redução significativa na suscetibilidade ao carbosulfam ao longo do ciclo da cultura. No entanto, foi observado um restabelecimento parcial da suscetibilidade ao carbosulfam no início da safra subseqüente, sugerindo assim a instabilidade da resistência. A razão de resistência 
de A. gossypii ao carbosulfam foi de 5,7 vezes. Não foi verificada a presença de resistência cruzada entre carbosulfam e os inseticidas tiametoxam e endosulfam. Estudos de dinâmica da resistência de A. gossypii ao carbosulfam realizados em condições de laboratório mostraram que a resistência é instável, ou seja, a freqüência de resistência diminui significativamente na ausência de pressão de seleção. Comparações de parâmetros biológicos entre as linhagens suscetível e resistente ao carbosulfam mostraram que há custo adaptativo associado à resistência. A linhagem resistente apresentou uma menor fecundidade, menor período reprodutivo e menor longevidade do que a linhagem suscetível. Por fim, trabalhos de avaliação da estratégia de mistura de inseticidas evidenciaram que a mistura de carbosulfam com tiametoxam ou endosulfam não é vantajoso no manejo da resistência de A. gossypii ao carbosulfam. 


\title{
BASES FOR AN INSECTICIDE RESISTANCE MANAGEMENT PROGRAM OF Aphis gossypii GLOVER, 1877 IN COTTON CROP
}

\author{
Author: ROBERTO HIROYUKI KONNO \\ Adviser: Prof. Dr. CELSO OMOTO
}

\section{SUMMARY}

The objective of this research was to collect basic information for building an insecticide resistance management program of Aphis gossypii Glover, 1877 in cotton crop. Baseline susceptibility data of A. gossypii to carbosulfan, thiamethoxam and endosulfan were characterized by the use of direct contact bioassay. Then, a susceptibility monitoring to these insecticides was conducted in populations of $A$. gossypii collected from Acreúna-GO, Ituverava-SP, Rondonópolis-MT and Unai-MG during 2001/2002 to 2003/2004 cotton growing seasons. The aphid collection was performed at the beginning, middle and end of cotton growing season. No significant differences in susceptibility to thiamethoxam and endosulfan were observed among A. gossypii populations. On the other hand, there was a significant decrease in the susceptibility to carbosulfan throughout the cotton growing season. However, a partial reset to the susceptibility to carbosulfan was observed at the beginning of the following cotton season. The resistance ratio of A. gossypii to carbosulfan was 5.7-fold. No cross-resistance between carbosulfan and the insecticides thiametoxam was observed. Studies on dynamics of A. gossypii resistance to carbosulfan conducted 
under laboratory conditions revealed that the resistance is unstable; that is, the frequency of resistance declines significantly in the absence of selection pressure. Life-history comparisons between carbosulfan-susceptible and resistant strains showed that there is some fitness cost associated to resistance. The resistant strain showed a lower fecundity, lower reproductive period and lower longevity than the susceptible strain. And finally, studies on evaluation of the strategy by mixing insecticides showed that the mixture of carbosulfan with thiamethoxam or endosulfan was not advantageous in the management of carbosulfan resistance in A. gossypii. 


\section{INTRODUÇÃO}

$\mathrm{O}$ algodão é uma das principais fibras têxteis utilizadas no mundo. $\mathrm{O}$ Brasil se encontra entre os maiores produtores mundiais, sendo que em 2003 a produção foi estimada em 850 mil toneladas de algodão em pluma, tendo uma projeção de crescimento de $2 \%$ ao ano. A região Centro-Oeste foi responsável por aproximadamente $70 \%$ da produção nacional, sendo os maiores produtores os estados de Mato Grosso (49 \%) e Goiás (14 \%) (FNP, 2004).

Dentre as pragas que atacam a cultura, o pulgão-do-algodoeiro Aphis gossypii Glover, 1877 (Hemiptera: Aphididae) tem se destacado como pragachave em algumas regiões no Brasil (Degrande, 2000; Santos, 1999). Esse inseto está presente desde o aparecimento das folhas cotiledonares até o final do ciclo da cultura, alimentando-se em tecidos tenros e meristemáticos (Degrande, 1998; Degrande, 2000; Leclant \& Deguine, 1994). Os danos diretos provocados pela sucção da seiva causam o definhamento e enfezamento das plantas, e assim comprometem a produção e a qualidade da fibra. Quanto aos danos indiretos estes insetos são vetores potenciais dos agentes virais causadores de doenças como o vermelhão-do-algodoeiro e o mosaico-das-nervuras. Além disso, a excreção de solução açucarada pelos pulgões pode afetar a qualidade das fibras e permitir o desenvolvimento da fumagina que interfere na fotossíntese (Degrande, 1998).

Problemas com A. gossypii têm emergido em muitos países produtores de algodão como Iraque, Israel, Síria, Estados Unidos e Brasil (Leclant \& Deguine, 1994). No Brasil, essa praga teve a sua importância aumentada a partir da 
expansão da cultura para o cerrado e com a introdução de cultivares originados dos Estados Unidos e Austrália os quais são suscetíveis às doenças virais conhecidas como mosaico-das-nervuras ou doença azul. Dessa forma, A. gossypii é considerado inseto vetor de vírus em alguns cultivares (p. ex. CNPA-ITA90, DELTAPINE ACALA90, IAC-22, SICALA 32 e FIBER MAX-966) e se tornou uma das pragas mais importante e limitante para a cultura do algodão. Em certas regiões, o pulgão foi responsável por até 80\% das pulverizações realizadas para o controle de pragas na cultura do algodão (Papa, 2001).

Um dos grandes entraves em programas de manejo integrado de pragas (MIP) envolvendo o uso de produtos químicos é a evolução da resistência (Croft, 1990; Denholm \& Rolland, 1992; Georghiou, 1983). Como conseqüências drásticas da evolução da resistência estão as aplicações de pesticidas com maior freqüência, uso de doses elevadas, misturas de pesticidas e/ou substituição por outro produto, geralmente de maior toxicidade e custo. Estas conseqüências comprometem os programas de MIP devido ao aumento no custo de controle, eliminação de inimigos naturais e maior contaminação do ambiente (Georghiou, 1983). Associado a esses fatores, a descoberta de uma nova molécula química tem se tornado cada vez mais difícil e cara. Portanto, os programas de manejo da resistência de pragas a pesticidas têm se tornado um importante componente do MIP.

O controle de A. gossypii na cultura do algodão no Brasil tem sido baseado principalmente no uso de inseticidas tanto em tratamento de sementes como em pulverizações. Produtores e técnicos têm observado falhas no controle de A. gossypii com o uso de alguns inseticidas em certas localidades nas principais regiões produtoras de algodão do país. Essas falhas estão relacionadas principalmente ao encurtamento do período de controle de A. gossypii e muitas vezes, para conseguir a mesma eficácia dos produtos, os produtores têm aumentado a dose do inseticida, principalmente em infestações tardias. Sem 
dúvida, fatores como a qualidade da pulverização, escolha do produto, nível de infestação da praga e condições climáticas podem afetar significativamente o desempenho dos produtos pulverizados. No entanto, devido ao aumento no uso de inseticidas para o controle de A. gossypii, a resistência a inseticidas também é um dos fatores que pode estar contribuindo para a redução da eficácia de alguns produtos.

Casos de resistência de A. gossypii a inseticidas têm sido reportados a produtos do grupo dos carbamatos, organofosforados e piretróides em localidades como na África (Gubran et al., 1992), nos Estados Unidos (Godfrey et al., 2000; Grafton-Cardwell, 1991), na Europa (Delorme et al., 1997), na Austrália (Herron et al., 2001), na China e no Japão (Leclant \& Deguine, 1994; Guilin et al., 1997).

Devido à carência de estudos na área de resistência a inseticidas em $A$. gossypii no Brasil, o objetivo principal do presente trabalho foi o de coletar informações básicas para um programa de manejo da resistência de A. gossypii a inseticidas na cultura do algodão. Para tanto, os objetivos específicos foram:

- Caracterizar a linha-básica de suscetibilidade de A. gossypii aos inseticidas carbosulfam, tiametoxam e endosulfam;

- Monitorar a suscetibilidade aos inseticidas carbosulfam, tiametoxam e endosulfam em populações de A. gossypii provindas das principais regiões produtoras de algodão;

- Caracterizar da resistência de A. gossypii ao carbosulfam;

- Estudar as relações de resistência cruzada entre carbosulfam e os inseticidas tiametoxam e endosulfam;

- Avaliar o custo adaptativo associado à resistência de A. gossypii ao carbosulfam;

- Avaliar a estratégia da mistura de inseticidas no manejo da resistência de A. gossyii ao carbosulfam. 


\section{REVISÃO DE LITERATURA}

\subsection{Resistência de Aphis gossypii a inseticidas}

O uso intensivo e indiscriminado de inseticidas tem causado uma rápida evolução da resistência em muitas espécies de inseto. A resistência tem sido definida como uma habilidade desenvolvida por uma população de um organismo em tolerar doses de um tóxico que seriam letais para a maioria dos indivíduos da população normal da espécie (World Health Organization citado por Croft \& Van de Bann, 1988).

Georghiou \& Tejeda (1991) relataram que até o final da década de 80, havia mais de 504 espécies de insetos e ácaros resistentes a pelo menos uma classe de composto químico. Desse total, 56,1\% das espécies eram de importância agrícola, 39,3\% de importância médico-veterinária e 4,6\% de importância benéfica. A ordem Hemiptera contribuiu com $24,4 \%$ das espécies resistentes reportadas, com predominância de várias espécies de afídeos. Estudos mais recentes indicaram a ocorrência de 536 espécies de insetos ou ácaros resistentes (Whalon et al., 2004).

Quando um pesticida tem a sua eficiência reduzida, os agricultores e técnicos tendem a aumentar a dose do produto aplicado, aumentar a freqüência de aplicação, utilizar a mistura de produtos e/ou substituir o produto ineficiente, por um outro, geralmente de maior toxicidade. Essas conseqüências da resistência 
comprometem os programas de manejo integrado de pragas (MIP), uma vez que causam maior contaminação do ambiente com pesticidas, maior destruição de organismos benéficos e aumento nos custos de produção (Georghiou, 1983).

O primeiro caso de resistência de Aphis gossypii a um inseticida foi relatado na China em 1964, com a detecção de uma linhagem resistente ao inseticida demetom (organofosforado) (Ghong et al., 1964 citados por Furk \& Hines, 1993). Posteriormente, vários casos de resistência de A. gossypii foram detectados a inseticidas de diferentes grupos químicos, tais como carbamatos, organofosforados, ciclodienos e piretróides (Delorme et al., 1997; GraftonCardwell, 1991; Gubran et al., 1992; Furk \& Hines, 1993; Furk et al., 1980; Kerns \& Gaylor, 1992; O’Brien et al., 1992).

Na Califórnia, Grafton-Cardwell (1991), por meio de um bioensaio de imersão e posterior contato residual, detectou resistência em A. gossypii, proveniente da cultura do algodoeiro, para oxidemetom-metil (razão de resistência (RR) de 4,42 vezes), dicrotofós ( $R R$ de 3,42 vezes), bifenate (3,51 vezes). Porém, nesse estudo não foi observada resistência para clorpirifós e endosulfam.

Gubran et al. (1992) avaliaram populações de A. gossypii coletadas em campos de algodão no Sudão. Os autores detectaram, por meio de bioensaio de contato direto, resistência a oito inseticidas: fenvalerate (RR de 652 vezes), deltametrina (RR de 167 vezes), metidatiom (RR de 857 vezes), dimetoato (RR de 112 vezes), pirimicarbi (RR de 87 vezes), metomil (RR de 2.700 vezes), endosulfam (RR de 369 vezes) e lindane (RR de 1.310 vezes).

A resistência a diversos inseticidas foi detectada em populações de $A$. gossypii coletadas em algodoeiro nos estados americanos do Alabama e Texas (Kerns \& Gaylor, 1992). Por meio de um bioensaio de contato residual, foram observadas razões de resistência de 20 e 50 vezes para os piretróides bifentrina e cipermetrina respectivamente. Para os inseticidas organofosforados, foram 
observadas resistência para dicrotofós (RR de 26 vezes), dimetoato (RR de 1,6 vezes), metamidofós (RR de 85 vezes), oxidemetom metil (RR de 12,4 vezes), fofamidom (RR de 12, 4 vezes) e profenós (RR de 8,5 vezes).

No Reino Unido, Furk \& Hines (1993) detectaram resistência aos inseticidas heptenofós (RR de 30 vezes) e diazinom (RR de 212 vezes) em populações de A. gossypii provenientes de cultivos comerciais de crisântemo e pepino. Para o inseticida pirimicarbi os autores não caracterizaram a resistência uma vez que a concentração máxima testada, sem que ocorresse a precipitação da calda, foi de $50.000 \mathrm{mg}$ de pirimicarbi/L de água e, nesta concentração a mortalidade da população resistente foi de apenas $26 \%$.

Populações de A. gossypii coletadas na cultura de pepino no Havaí (Estados Unidos) mostraram uma razão de resistência 3,6 vezes ao inseticida endosulfam (ciclodieno), 390 vezes ao inseticida esfenvalerate (piretróide), 9,2 vezes ao metomil (carbamato) e $>2.000$ vezes para oxidemetom-metil (organofosforado) (Hollingsworth et al., 1994).

Na China, Guilin et al. (1997) avaliaram populações provenientes de cultivo comercial de algodão, utilizando bioensaio de aplicação tópica. A resistência foi detectada para deltametrina (RR de até 16.500 vezes), fenvalerate (RR de 6.500 vezes), monocrotofós (RR de 2.068 vezes), paratiom (RR de 297 vezes), ometoato (RR de 1.300 vezes), metomil (RR de 29 vezes) e aldicarbi (RR de 5 vezes). Os autores não detectaram resistência para o inseticida imidacloprido (neonicotinóide).

Wang et al. (2002) selecionaram linhagens de A. gossypii resistente ao fenvalerate e ao imidacloprido, a partir de pulgões provenientes da cultura de algodão e pepino. Para as linhagens provenientes de algodoeiro, foi detectada resistência para fenvalerate (RR de 29.500 vezes) e para o imidacloprido (RR de 4,7 vezes). Nas linhagens provenientes da cultura do pepino, as razões de 
resistência detectadas para fenvalerate e imidacloprido foram de 700 e 3,8 vezes respectivamente.

Quanto aos mecanismos de resistência de A. gossypii a inseticidas, alguns trabalhos têm demonstrado que a alteração do sítio de ação do produto e o aumento na taxa de destoxificação são os dois principais mecanismos de resistência envolvidos. Delorme et al. (1997) concluíram que o mecanismo de resistência de A. gossypii a pirimicarbi foi devido à diminuição da sensibilidade do sítio de ação do inseticida. Nesse mesmo trabalho, os autores observaram por meio de testes com o sinergista butóxido de piperonila que o mecanismo de resistência baseado no aumento da destoxificação enzimática mediada pelo citocromo P-450 apresentava uma importância secundária. O’Brien et al. (1992) verificaram que o mecanismo de resistência de A. gossypii a carbamatos e organofosforados estava relacionado principalmente ao aumento da atividade da enzima carboxiesterase.

\subsection{Fatores que afetam a evolução da resistência de Aphis gossypii a inseticidas}

O processo determinante no desenvolvimento da resistência é a pressão de seleção exercida por constantes aplicações de um determinado produto químico. No início da evolução da resistência, estima-se que a freqüência de alelos de resistência em uma população seja baixa, na ordem de $10^{-13}$ a $10^{-2}$ (Roush \& McKenzie, 1987). Georghiou \& Taylor (1977a, b) dividiram os fatores que afetam a evolução da resistência em genéticos, bioecológicos e operacionais. 


\subsubsection{Fatores genéticos}

Os fatores genéticos estão relacionados ao número de genes envolvidos na resistência, padrão de herança da resistência e valor adaptativo dos indivíduos resistentes (Roush \& McKenzie, 1987). O gênero Aphis apresenta um número reduzido de cromossomos, $n=4$ (Blackman, 1987). Em função dessa característica, A. gossypii apresenta grandes chances de que dois ou mais mecanismos distintos de resistência se localizem num mesmo cromossomo. Assim, a utilização de um determinado inseticida pode levar à seleção de indivíduos resistentes a um outro grupo de inseticidas, se os genes que conferem resistência a estes dois grupos de inseticidas estiverem presentes no mesmo cromossomo.

As diferenças no valor adaptativo entre indivíduos suscetíveis e resistentes de uma população também podem afetar a evolução da resistência (Roush \& McKenzie, 1987). Trabalhos realizados por Hollingsworth et al. (1997), avaliaram o valor adaptativo de linhagens de A. gossypii suscetível e resistente a inseticidas. Os autores observaram um custo adaptativo associado ao inseticida esfenvalerate, isto é, a linhagem resistente apresentou uma menor fecundidade em relação à suscetível. Não foi observado custo adaptativo para as linhagens resistentes ao endosulfam e oxidemetom-metil com relação à fecundidade. Por outro lado, a linhagem resistente ao metomil apresentou uma relação direta entre fecundidade e intensidade de resistência, isto é a linhagem resistente apresentou uma maior fecundidade em relação à suscetível, possivelmente devido ao processo de co-adaptação. 


\subsubsection{Fatores bioecológicos}

A reprodução de A. gossypii, em condições de clima temperado, ocorre de forma sexuada (início da primavera) e por partenogênese telítoca (períodos quentes). Durante a reprodução sexuada, os cromossomos holocêntricos (centrômeros não apresentam uma localização definida) têm a capacidade de se fragmentarem em vários pontos durante a mitose, para formar produtos de dissociação estáveis, resultando em maior variabilidade genética. Essa variabilidade genética é mantida devido à reprodução por partenogênese telítoca (Blackman, 1987; Dixon, 1987). Por outro lado, em condições de clima tropical a reprodução ocorre exclusivamente por partenogênese telítoca. No caso, os descendentes apresentam as mesmas características genéticas da progenitora, isto é, se a progenitora for resistente a um determinado inseticida, todos os seus descendentes também serão.

Associado ao modo de reprodução, outro fator que influência a evolução da resistência é o alto potencial biótico apresentado pelos pulgões. Segundo Georghiou \& Taylor (1977), organismos que apresentam várias gerações por ano, desenvolvem resistência com mais freqüência e de forma mais rápida que organismos que apresentam poucas gerações por ano.

O desenvolvimento de A. gossypii foi estudado por Vendramim \& Nakano (1981) que avaliaram a biologia em plantas de algodão. Nesse trabalho, os autores observaram que a coloração dos descendentes foi idêntica à da mãe, o número de ínstares foi igual a quatro e a duração da fase ninfal média foi de 5,9 dias. O período reprodutivo durou em média 21,9 dias. O número médio de ninfas produzidas por fêmea foi de 47,2. Dessa forma, o alto potencial biótico da espécie fez com que em poucos dias ocorresse um rápido crescimento da população, sendo necessária a adoção constante de medidas de controle. 
Os pulgões apresentam um meio eficiente de dispersão e colonizam rapidamente e eficientemente a nova fonte de alimento. A movimentação dos pulgões pode ocorrer por meios passivos ou ativos. Ninfas e adultos podem caminhar sobre as folhas ou solo, resultando numa permanente redistribuição demográfica da população. Já os indivíduos alados podem voar ou serem arrastados por correntes de ar a distâncias consideráveis e são responsáveis pela dispersão (vôo migratório) da espécie (Robert, 1987). Uma vez alcançada a planta hospedeira, os indivíduos alados iniciam o processo de alimentação e reprodução, colonizando a planta (Santos, 1999; Santos, 2000).

O pulgão-do-algodoeiro é uma espécie bastante polífaga, sendo encontrada em diversas espécies de plantas cultivadas ou daninhas (Delorme et al., 1997; Godfrey et al., 2000). Sendo assim, essas plantas poderiam servir de refúgio para os indivíduos suscetíveis e a imigração destes insetos para as plantas de algodão pode resultar em uma redução na freqüência de resistência.

\subsubsection{Fatores operacionais}

Os fatores operacionais são divididos em dois grupos: (1) referente às características do produto químico (persistência, formulação, seletividade a inimigos naturais e grupo químico) e (2) referente às características de aplicação do produto (nível de controle, estágio de desenvolvimento da praga, modo de aplicação e estratégias de uso dos produtos). Os fatores operacionais são os passíveis de serem alterados dentro de um contexto de manejo da resistência, uma vez que os fatores genéticos e bioecológicos são características intrínsecas do organismo (Georghiou \& Taylor, 1977a, b).

Na instalação da cultura do algodão, o uso de inseticidas na forma de tratamento de sementes ou de inseticidas granulados no solo é uma prática comum, pois além de atuar contra tripes, brocas e percevejos castanho, controla 
também as infestações iniciais de pulgão. Entre os inseticidas recomendados para esse fim estão carbofuram, carbosulfam, aldicarb tiametoxam, imidacloprid, etc. Em média, o tratamento de sementes confere controle satisfatório até os 25 dias após a emergência das plantas (Degrande, 1998; Santos, 1999; Santos, 2000). Se por um lado um inseticida oferece maior período de controle, por outro lado este produto a submete a uma maior pressão de seleção de indivíduos resistentes da praga. Portanto, no caso de $A$. gossypii, três gerações sucessivas sofrerão pressão de seleção de um mesmo inseticida utilizado em tratamento de sementes. A elevada persistência da atividade biológica desses produtos pode proporcionar uma evolução mais rápida da resistência quando comparado a produtos de menor persistência (Taylor \& Georghiou, 1982).

O nível de controle de $A$. gossypii na cultura do algodão depende da variedade cultivada. Em cultivares resistentes a viroses (CNPA-ITA 96, CODETEC 401, BRS FACUAL, BRS ANTARES, DELTAOPA etc), o nível de controle de A. gossypii é atingido quando a lavoura apresentar $40 \%$ de plantas atacadas. Por outro lado, cultivares suscetíveis a viroses (CNPA-ITA90, DELTAPINE ACALA 90, IAC-22, SICALA 32, FABER MAX-966 etc) o nível de controle adotado é de $2 \%$ a $10 \%$ de plantas infestadas com pulgões (Degrande, 1998; Santos, 1999; Santos, 2000).

Na região do cerrado, as lavouras de algodão, cultivadas com cultivares suscetíveis a viroses, necessitam de uma intensa proteção contra os pulgões, o que culmina com o uso excessivo de inseticidas. Muitas lavouras recebem até 15 aplicações de inseticidas não seletivos como produtos do grupo dos carbamatos e organofosforados a cada ciclo da cultura (Papa, 2001). Em função do seu efeito de choque, o carbosulfam constitui-se no principal inseticida utilizado no controle de A. gossypii e, tem sido bastante comum a sua utilização em mistura com outros inseticidas (Costa, 200; Santos, 1999). Além de sofrer pressão de seleção com os inseticidas utilizados para seu controle, pelo fato de $A$. gossypii estar presente 
durante todo o ciclo da cultura do algodão, esta praga também sofre as pressões de seleção de todos os inseticidas aplicados para o controle de outras pragas. Dessa forma, o risco de evolução da resistência a inseticidas é alto para essa espécie.

A compreensão dos fatores envolvidos no desenvolvimento da resistência é de fundamental importância para a implementação de programas de manejo da resistência que visam prevenir, retardar ou reverter a evolução da resistência de pragas a pesticidas (Georghiou \& Taylor, 1986) 


\section{MATERIAL E MÉTODOS}

O presente projeto de pesquisa foi desenvolvido no Laboratório de Resistência de Artrópodes a Pesticidas do Departamento de Entomologia, Fitopatologia e Zoologia Agrícola da ESALQ/USP, Piracicaba-SP, no período de 2001 a 2004.

\subsection{Criação de Aphis gossypii em laboratório}

Populações de A. gossypii coletadas nas principais regiões produtoras de algodão foram trazidas para o laboratório por via aérea ou terrestre. Cada população teve início com 300 a 400 pulgões (ninfas e adultos).

As diferentes populações/linhagens de A. gossypii foram mantidas em gaiolas teladas (dimensões de $30 \times 30$ x $50 \mathrm{~cm}$ ), as quais permaneceram em sala climatizada à temperatura de $25 \pm 1^{\circ} \mathrm{C}$, fotofase de 14 h e UR de $60 \pm 10 \%$. Como substrato de alimentação foram utilizadas plantas de algodão da variedade DELTA OPAL livres de resíduos de pesticidas. As mudas de algodão foram produzidas em vasos plásticos de 0,5 L de capacidade contendo substrato para produção de mudas de hortaliça (Plantimax HT ${ }^{\circledR}$ - Eucatex Ltda., Paulínia-SP). As mudas foram produzidas estufa telada (tela antiafídica), para evitar a entrada de pulgões e outros insetos. Com o intuito de evitar o surgimento de indivíduos 
alados devido ao aumento excessivo na densidade populacional, a substituição dos vasos de plantas de algodão dentro das gaiolas de criação foi efetuada semanalmente.

\subsection{Procedimentos de bioensaio}

A resposta das populações/linhagens de A. gossypii aos inseticidas carbosulfam (Marshal 400 SC $^{\circledR}$ - suspensão concentrada, 400 g de ingrediente ativo (I.A.)/L, FMC do Brasil Indústria e comércio Ltda.), tiametoxam (Actara $250 \mathrm{WG}^{\circledR}$ - granulado dispersível, 250 g de I.A./kg, Syngenta Proteção de Plantas Ltda.) e endosulfam (Thiodan CE - concentrado emulsionável, 350 g de I.A./L, Bayer CropScience Ltda.) foi avaliada por meio de um bioensaio do tipo contato residual. Discos de folhas de algodão, obtidas de plantas mantidas em vasos dentro de estufa e sem aplicações de inseticidas, 2,5 cm de diâmetro foram pulverizados na superfície abaxial com torre de Potter (Burkard Manufacturing, Rickmansworth, Englaterra) calibrada a 68,95 kPa .

Um volume de $2 \mathrm{~mL}$ de calda, obtida por meio da diluição dos produtos comerciais em água destilada, foi utilizado na pulverização de modo a obter uma deposição média de $1,5 \mathrm{mg}$ da calda/ $\mathrm{cm}^{2}$. Após a pulverização, os discos de folhas foram transferidos para placas de Petri de 3,5 cm de diâmetro, contendo com uma camada de ágar-água a 3 \%. Cada arena foi infestada com dez pulgões adultos ápteros, com o auxílio de um pincel de pêlos finos e microscópio estereoscópio. Após a transferência dos pulgões nas arenas, as placas foram fechadas e mantidas em câmaras climatizadas à temperatura de $25 \pm 1^{\circ} \mathrm{C}$ e fotofase de 14 h. Os bioensaios que apresentaram mortalidade de pulgões superior a $20 \%$ na testemunha foram descartados. 
Para os inseticidas carbosulfam e endosulfam, a mortalidade foi avaliada após 24 horas. Para o inseticida tiametoxam, a mortalidade foi avaliada 48 horas após transferência dos pulgões. O critério de mortalidade foi baseado no toque de cada pulgão com um pincel e os indivíduos que não responderam com movimentos vigorosos de seus apêndices foram considerados mortos.

\subsection{Caracterização da linha-básica de suscetibilidade de Aphis gossypii a inseticidas}

A linhagem suscetível de referência de A. gossypii foi obtida em plantas de algodão no município de Piracicaba-SP e tem sido mantida em laboratório, na ausência de pressão seletiva com inseticidas desde 1999.

Para a caracterização toxicológica da linhagem suscetível de referência de A. gossypii aos inseticidas carbosulfam, tiametoxam e endosulfam foram utilizadas 5 concentrações de 3,2 a 32, de 1 a 25 e 100 a 500 mg de I.A./L respectivamente. Cada concentração foi repetida 4 a 5 vezes, sendo que em cada repetição foram utilizados aproximadamente 40 pulgões.

Os dados de resposta obtidos para a população suscetível de referência aos diversos inseticidas foram submetidos à análise de Probit (LeOra Software, 1987). Com base na resposta da população suscetível foi determinada uma concentração diagnóstica para cada produto, seguindo os critérios apresentados por Roush \& Miller (1986) e ffrench-Constant \& Roush (1990). Essas concentrações diagnósticas foram utilizadas no monitoramento da suscetibilidade de populações de A. gossypii aos inseticidas carbosulfam, tiametoxam e endosulfam. 


\subsection{Monitoramento da suscetibilidade de Aphis gossypii a inseticidas}

O monitoramento da suscetibilidade de A. gossypii a inseticidas foi realizado em populações coletadas na cultura do algodão nas safras de 2001/2002, 2002/2003 e 2003/2004, das regiões de Acreúna-GO, Ituverava-SP, Rondonópolis-MT e Unai-MG.

Em cada safra e região foram coletadas duas a três populações de uma mesma localidade, sendo que a primeira coleta foi realizada entre as fases de emergência à primeira flor, a segunda entre as fases da primeira flor ao primeiro capulho e a terceira na fase de abertura do capulho à colheita (Rosolem, 2001). As características da cultura e o histórico de aplicação de inseticidas em cada região nas três safras encontram-se nos Quadros 1, 2, 3 e 4.

As populações de A. gossypii trazidas do campo foram criadas no Laboratório de Resistência de Artrópodes a Pesticidas por duas a três gerações até a obtenção de um número suficiente de indivíduos para realizar os bioensaios. $\mathrm{O}$ monitoramento da suscetibilidade foi realizado por meio da utilização das concentrações diagnósticas dos inseticidas carbosulfam (32 mg de I.A./L), tiametoxam (25 mg de I.A./L) e endosulfam (500 mg de I.A./L) que foram determinadas mediante a caracterização da linha básica de suscetibilidade.

Para cada população coletada, os bioensaios foram repetidos quatro vezes (cinco arenas por repetição, contendo 10 pulgões por arena). Em cada bioensaio foram utilizadas duas arenas tratadas apenas com água destilada, como testemunhas. Os bioensaios foram mantidos em câmara climatizada. A sobrevivência foi avaliada após $24 \mathrm{~h}$ da transferência para carbosulfam e endosulfam e após 48 horas para tiametoxam.

Os dados de porcentagem de sobrevivência $(X)$ das populações para cada região e safra foram transformados em arc sen $\sqrt{(X / 100)}$. As médias de 
sobrevivência foram comparadas pelo teste de Tukey. O nível de significância dos testes foi de $\alpha=0,05$. 


\begin{tabular}{|c|c|c|c|c|c|}
\hline Safra & Plantio & Variedade & Coleta & $\begin{array}{c}\text { Data da } \\
\text { coleta }\end{array}$ & $\begin{array}{c}\text { Número de } \\
\text { aplicações de } \\
\text { inseticidas }\end{array}$ \\
\hline \multirow[t]{11}{*}{ 2001/2002 } & $12 / 2001$ & Codetec- & 1 & 28/12/2001 & carbofuram (TS*) \\
\hline & & 404 & 2 & 25/01/2002 & 1 carbosulfam \\
\hline & & (resistente & & & 1 endosulfam \\
\hline & & a viroses) & & & 1 metomil \\
\hline & & & & & 1 clorpirifós \\
\hline & & & & & 1 profenós \\
\hline & & & 3 & 05/04/2002 & 3 carbosulfam \\
\hline & & & & & 2 endosulfam \\
\hline & & & & & 1 acetamiprido \\
\hline & & & & & 1 zetacipermetrin \\
\hline & & & & & 1 lufenurom \\
\hline \multirow[t]{8}{*}{ 2002/2003 } & $12 / 2002$ & Delta Opal & 1 & $17 / 01 / 2003$ & 1carbofuram (TS) \\
\hline & & (resistente & & & 1 monocrotofós \\
\hline & & a viroses) & & & 1 profenós \\
\hline & & & 2 & $20 / 02 / 2003$ & 2 carbosulfam \\
\hline & & & & & 1 tiametoxam \\
\hline & & & & & 2 endosufam \\
\hline & & & & & 2 lufenurom \\
\hline & & & & & 1 clorpirifós \\
\hline \multirow[t]{14}{*}{ 2003/2004 } & $12 / 2003$ & Faber Max & 1 & $17 / 01 / 2004$ & carbofuram (TS) \\
\hline & & 966 & & & 1 carbosulfam \\
\hline & & (suscetível & & & 1 endosulfam \\
\hline & & a viroses) & 2 & $16 / 02 / 2004$ & 3 carbosulfam \\
\hline & & & & & 1 endosulfam \\
\hline & & & & & 1 acetamiprido \\
\hline & & & & & 1 metomil \\
\hline & & & 3 & $12 / 04 / 2004$ & 5 carbosulfam \\
\hline & & & & & 1 tiametoxam \\
\hline & & & & & 2 metomil \\
\hline & & & & & 1 profenós \\
\hline & & & & & 1 diafentiurom \\
\hline & & & & & 1 novalurom \\
\hline & & & & & 1 zetacipermetrin \\
\hline
\end{tabular}

TS = tratamento de semente

Quadro 1- Época de plantio do algodão, variedade, data de coleta e histórico de aplicação de inseticidas durante o ciclo da cultura para as populações de A. gossypii da região de Acreúna-GO nas safras 2001/2002, 2002/2003 e 2003/2004 


\begin{tabular}{|c|c|c|c|c|c|}
\hline Safra & Plantio & Variedade & Coleta & $\begin{array}{c}\text { Data da } \\
\text { coleta }\end{array}$ & $\begin{array}{c}\text { Número de } \\
\text { aplicações de } \\
\text { inseticidas }\end{array}$ \\
\hline \multirow[t]{2}{*}{$2001 / 2002$} & $11 / 2001$ & $\begin{array}{l}\text { Delta Opal } \\
\text { (resistene a } \\
\text { viroses) }\end{array}$ & 1 & $19 / 01 / 2002$ & $\begin{array}{l}\text { carbofuram(TS*) } \\
1 \text { clorpirifós } \\
1 \text { tiametoxam } \\
1 \text { endosulfam }\end{array}$ \\
\hline & & & 2 & 28/02/2002 & $\begin{array}{l}3 \text { carbosulfam } \\
1 \text { profenós } \\
2 \text { zetacipermetrin } \\
1 \text { diafentiurom } \\
2 \text { lufenurom }\end{array}$ \\
\hline \multirow[t]{2}{*}{$2002 / 2003$} & $12 / 2002$ & $\begin{array}{l}\text { Delta Opal } \\
\text { (resisente a } \\
\text { viroses) }\end{array}$ & 1 & $25 / 01 / 2003$ & $\begin{array}{l}\text { carbofuram (TS) } \\
1 \text { carbosulfam } \\
1 \text { tiametoxam } \\
1 \text { endosulfam } \\
1 \text { clorpirifós }\end{array}$ \\
\hline & & & 2 & 25/02/2003 & $\begin{array}{l}2 \text { carbosulfam } \\
1 \text { lambidacialotrin } \\
1 \text { diafentiurom } \\
1 \text { lufenurom }\end{array}$ \\
\hline \multirow[t]{3}{*}{$2003 / 2004$} & $12 / 2003$ & $\begin{array}{l}\text { Delta Opal } \\
\text { (resisente a } \\
\text { viroses) }\end{array}$ & 1 & $26 / 01 / 2004$ & $\begin{array}{l}\text { carbofuram (TS) } \\
1 \text { carbosulfam } \\
1 \text { endosulfam } \\
1 \text { zetacipermetrin } \\
1 \text { profenós } \\
1 \text { lufenurom }\end{array}$ \\
\hline & & & 2 & $25 / 02 / 2004$ & $\begin{array}{l}1 \text { diafentiurom } \\
1 \text { lufenurom } \\
1 \text { profenós }\end{array}$ \\
\hline & & & 3 & 29/03/2004 & $\begin{array}{l}4 \text { carbosulfam } \\
2 \text { zetacipermetrin } \\
2 \text { diafentiurom } \\
1 \text { lufenurom }\end{array}$ \\
\hline
\end{tabular}

TS = tratamento de semente

Quadro 2- Época de plantio do algodão, variedade, data de coleta e histórico de aplicação de inseticidas durante o ciclo da cultura para as populações de A. gossypii da região de Ituverava-SP nas safras 2001/2002, $2002 / 2003$ e $2003 / 2004$ 


\begin{tabular}{|c|c|c|c|c|c|}
\hline Safra & Plantio & Variedade & Coleta & $\begin{array}{c}\text { Data da } \\
\text { coleta }\end{array}$ & $\begin{array}{c}\text { Número de } \\
\text { aplicações de } \\
\text { inseticidas }\end{array}$ \\
\hline \multirow[t]{2}{*}{$2001 / 2002$} & $11 / 2001$ & $\begin{array}{l}\text { Delta Opal } \\
\text { (resistente } \\
\text { a viroses) }\end{array}$ & 1 & 23/01/2002 & $\begin{array}{l}\text { carbofuram }\left(\mathrm{TS}^{*}\right) \\
1 \text { carbosulfam } \\
1 \text { profenós } \\
1 \text { monocrotofós }\end{array}$ \\
\hline & & & 2 & 28/02/2002 & $\begin{array}{l}3 \text { carbosulfam } \\
1 \text { tiametoxam } \\
1 \text { endosulfam } \\
1 \text { acetamiprido }\end{array}$ \\
\hline \multirow[t]{2}{*}{$2002 / 2003$} & $12 / 2002$ & $\begin{array}{l}\text { Codetec } 401 \\
\text { (resistente } \\
\text { a viroses) }\end{array}$ & 1 & 29/01/2003 & $\begin{array}{l}\text { carbofuram (TS) } \\
2 \text { carbosulfam } \\
1 \text { endosulfam } \\
1 \text { profenós }\end{array}$ \\
\hline & & & 2 & 27/03/2002 & $\begin{array}{l}3 \text { carbosulfam } \\
1 \text { tiametoxam } \\
1 \text { metomil } \\
\text { 1zetacipermetrin } \\
1 \text { lufenurom }\end{array}$ \\
\hline \multirow[t]{3}{*}{ 2003/2004 } & $12 / 2003$ & $\begin{array}{l}\text { Faber Max } \\
966 \\
\text { (suscetível } \\
\text { a viroses) }\end{array}$ & 1 & $23 / 01 / 2004$ & $\begin{array}{l}\text { carbofuram (TS) } \\
3 \text { carbosulfam } \\
1 \text { tiametoxam } \\
1 \text { endosulfam } \\
1 \text { metomil }\end{array}$ \\
\hline & & & 2 & $23 / 02 / 2004$ & $\begin{array}{l}4 \text { carbosulfam } \\
3 \text { endosulfam } \\
1 \text { metomil } \\
1 \text { profenós } \\
2 \text { novalurom }\end{array}$ \\
\hline & & & 3 & $31 / 03 / 2004$ & $\begin{array}{l}4 \text { carbosulfam } \\
1 \text { tiametoxam } \\
1 \text { diafentiurom } \\
2 \text { novalurom } \\
2 \text { indoxacarb }\end{array}$ \\
\hline
\end{tabular}

TS = tratamento de semente

Quadro 3- Época de plantio do algodão, variedade, data de coleta e histórico de aplicação de inseticidas durante o ciclo da cultura para as populações de A. gossypii da região de Rondonópolis-MT nas safras 2001/2002, 2002/2003 e 2003/2004 


\begin{tabular}{|c|c|c|c|c|c|}
\hline Safra & Plantio & Variedade & Coleta & $\begin{array}{c}\text { Data da } \\
\text { coleta }\end{array}$ & $\begin{array}{c}\text { Número de } \\
\text { aplicações de } \\
\text { inseticidas }\end{array}$ \\
\hline \multirow[t]{2}{*}{$2001 / 2002$} & $12 / 2001$ & $\begin{array}{l}\text { Delta Opal } \\
\text { (resistente } \\
\text { a viroses) }\end{array}$ & 1 & $16 / 02 / 2002$ & $\begin{array}{l}\text { carbofuram (TS*) } \\
1 \text { monocrotofós } \\
1 \text { profenós } \\
1 \text { clorpirifós } \\
1 \text { benfuracarbe }\end{array}$ \\
\hline & & & 2 & 20/03/2002 & $\begin{array}{l}2 \text { carbosulfam } \\
2 \text { endosulfam } \\
1 \text { clorpirifós } \\
1 \text { lufenurom }\end{array}$ \\
\hline \multirow[t]{2}{*}{$2002 / 2003$} & $12 / 2002$ & $\begin{array}{l}\text { Delta Opal } \\
\text { (resistente } \\
\text { a viroses) }\end{array}$ & 1 & 20/01/2003 & $\begin{array}{l}\text { carbofuram (TS) } \\
2 \text { carbosulfam } \\
2 \text { endosulfam } \\
1 \text { lufenurom }\end{array}$ \\
\hline & & & 2 & 28/03/2003 & $\begin{array}{l}2 \text { carbosulfam } \\
1 \text { tiametoxam } \\
1 \text { endosulfam } \\
1 \text { profenós } \\
1 \text { lufenurom } \\
1 \text { zetacipermetrin }\end{array}$ \\
\hline \multirow[t]{3}{*}{ 2003/2004 } & $12 / 2003$ & $\begin{array}{l}\text { Delta Opal } \\
\text { (resistente } \\
\text { a viroses) }\end{array}$ & 1 & $19 / 01 / 2004$ & $\begin{array}{l}\text { carbofuram (TS) } \\
2 \text { carbosulfam } \\
1 \text { endosulfam } \\
1 \text { clorfluazurom }\end{array}$ \\
\hline & & & 2 & $25 / 02 / 2004$ & $\begin{array}{l}1 \text { profenós } \\
1 \text { betaciflutrina }\end{array}$ \\
\hline & & & 3 & 05/04/2004 & $\begin{array}{l}3 \text { carbosulfam } \\
1 \text { tiametoxam } \\
2 \text { endosulfam } \\
1 \text { metomil } \\
1 \text { clorfluazurom }\end{array}$ \\
\hline
\end{tabular}

TS = tratamento de semente

Quadro 4- Época de plantio do algodão, variedade, data de coleta e histórico de aplicação de inseticidas durante o ciclo da cultura para as populações de A. gossypii da região de Unai-MG nas safras 2001/2002, 2002/2003 e $2003 / 2004$ 


\subsection{Isolamento e caracterização da resistência de Aphis gossypii ao inseticida carbosulfam}

O isolamento da linhagem de $A$. gossypii resistente ao inseticida carbosulfam foi realizado em condições de laboratório, a partir de uma população proveniente de cultivo comercial de algodão da região de Ituverava-SP. Esta população foi submetida à concentração diagnóstica do inseticida carbosulfam (CL ${ }_{95}=32 \mathrm{mg}$ de I.A./L) de acordo com os procedimentos de bioensaio descritos anteriormente. Os pulgões sobreviventes foram transferidos para uma nova planta para multiplicação e, após duas a três gerações os pulgões foram submetidos a uma segunda seleção com o inseticida carbosulfam. No total, foram realizadas quatro etapas de seleção utilizando a concentração diagnóstica de $32 \mathrm{mg}$ de I.A./L, sendo que no final desse processo a população resultante foi considerada como uma linhagem resistente ao inseticida carbosulfam.

A caracterização da linhagem resistente ao carbosulfam foi realizada por meio da utilização de cinco concentrações entre 18 e 180 mg de I.A./ L de água. Os dados de resposta obtidos para as linhagens resistente e suscetível foram submetidos à análise de Probit (LeOra Software, 1987). A razão de resistência foi estimada pela divisão da $\mathrm{CL}_{50}$ da linhagem resistente pela $\mathrm{CL}_{50}$ da linhagem suscetível e o respectivo intervalo de confiança (IC) a 95\% da razão de resistência foi determinado de acordo com o método descrito por Robertson \& Preisler (1992).

\subsection{Relações de resistência cruzada entre carbosulfam e os inseticidas tiametoxam e endosulfam}

A verificação das possíveis relações de resistência cruzada entre o carbosulfam e os inseticidas tiametoxam e endosulfam foi realizada por meio da 
caracterização da linhagem resistente de Aphis gossypii ao carbosulfam a esses dois inseticidas. As caracterizações das linhas-básicas de suscetibilidade aos inseticidas tiametoxam e endosulfam já foram reportadas no item 3.3.

Cinco concentrações que proporcionaram mortalidade entre 5 a $95 \%$ na linhagem resistente ao carbosulfam e espaçadas logaritmicamente foram definidas para cada inseticida. Cada concentração foi repetida 5 a 6 e cada repetição foi constituída de 40 pulgões.

Os dados de mortalidade de cada inseticida foram submetidos à análise de Probit através do programa POLO-PC (LeOra Software, 1987). Um teste de paralelismo e igualdade das linhas de concentração-resposta de cada produto para as linhagens suscetível e resistente foi realizado. As relações de resistência cruzada entre os produtos estudados foram obtidas através da análise de sobreposição ou não dos intervalos de confiança das $\mathrm{CL}_{50 \text { s }}$ estimadas de cada produto para as linhagens suscetível e resistente (Robertson \& Preisler, 1992). O nível de significância adotado para os testes foi de $\alpha=0,05$.

\subsection{Custo adaptativo associado à resistência de Aphis gossypii ao inseticida carbosulfam}

A avaliação do custo adaptativo associado à resistência de A. gossypii ao inseticida carbosulfam foi avaliada mediante estudos de dinâmica da resistência em condições de laboratório, a partir do monitoramento da sobrevivência em populações com freqüências de 20,50 e 80 \% de pulgões resistentes. O monitoramento foi realizado por um período de seis meses por meio do uso da concentração diagnóstica de $32 \mathrm{mg}$ de carbosulfam/L. Além desse estudo, a biologia das linhagens de $A$. gossypii suscetível e resistente ao inseticida 
carbosulfam foi avaliada em condições de laboratório e a tabelas de vida e fertilidade foram obtidas para as duas linhagens

\subsubsection{Dinâmica da resistência de Aphis gossypii ao inseticida carbosulfam em condições de laboratório}

A partir das linhagens suscetível e resistente de A. gossypii ao inseticida carbosulfam foram constituídas três populações com freqüência de 20 \%, 50 \% e 80\% de pulgões resistentes. Para a formação de cada população foram utilizadas quatro plantas de algodão de 40 dias de idade, sendo que cada planta foi infestada com 100 pulgões. As populações assim formadas foram acondicionadas em gaiolas teladas mantidas em sala climatizada (temperatura de $25 \pm 1{ }^{\circ} \mathrm{C}$ e fotofase de $14 \mathrm{~h})$.

A suscetibilidade das populações ao carbosulfam foi monitorada mensalmente, durante seis meses, por meio de bioensaios com a utilização da concentração diagnóstica de $32 \mathrm{mg} / \mathrm{L}$ de carbosulfam. Os bioensaios foram repetidos quatro vezes, sendo que cada repetição constou com quatro arenas, contendo 10 pulgões adultos ápteros. Na testemunha foram utilizadas duas arenas tratadas apenas com água destilada.

A porcentagem de sobrevivência $(X)$ de cada população ao longo dos seis meses, foram transformados em $\operatorname{arc} \operatorname{sen}(\sqrt{X / 100})$ e submetidos à análise de variância de dois fatores (população e tempo) e o nível de significância adotado foi de $\alpha=0,05$. 


\subsubsection{Biologia das linhagens de Aphis gossypii suscetível e resistente ao inseticida carbosulfam em condições de laboratório}

A biologia das linhagens de $A$. gossypii suscetível e resistente ao carbosulfam foi avaliada em condições de laboratório, à temperatura de $25 \pm 1^{\circ} \mathrm{C}$ e fotofase de 14 h. Plantas de algodão de 40 dias de idade mantidas em vasos foram utilizadas como hospedeiro. Para confinar o pulgão foi utilizada uma gaiola acrílica de $3 \mathrm{~cm}$ de diâmetro, tendo em seu centro um orifício de 1,2 cm de diâmetro e 0,4 cm de espessura. Em uma das faces da gaiola, uma tela do tipo “organza” foi colada com a finalidade de confinar o pulgão e permitir troca de gases e umidade. Essa gaiola foi fixada em uma folha madura com o auxílio de um grampo de latão, sendo fixada apenas uma gaiola por planta.

Em cada gaiola foram transferidos três pulgões adultos ápteros da linhagem a ser estudada. Os pulgões permaneceram por seis horas nas gaiolas para a obtenção de ninfas. Após esse período, todos os pulgões foram retirados, deixando-se apenas uma ninfa. Dessa forma, o acompanhamento da biologia foi iniciado com ninfas de 0 a 6 horas de idade. As avaliações durante o período ninfal foram realizadas duas vezes ao dia, sempre às 8:00 e 17:00 horas, anotando-se a duração e a mortalidade de cada estágio. Após a emergência dos adultos as avaliações foram realizadas apenas uma vez ao dia (às 8:00 horas), sendo registrados a duração dos períodos de pré-reprodução, período reprodutivo, pós-reprodutivo, número de ninfas por fêmea e longevidade.

Os dados dos parâmetros biológicos observados para cada linhagem foram analisados através do teste $F$, ao nível de significância de $\alpha=0,05$. Tabelas de vida e fertilidade para duas linhagens foram obtidas através do método proposto por Andrewartha \& Birch (1954) citados por Silveira Neto et al. (1976). Os parâmetros da tabela de vida e fertilidade estimados para as duas linhagens estão reportados nos Apêndices 1 e 2. 


\subsection{Efeito de mistura de inseticidas e dos produtos isolados sobre as linhagens de Aphis gossypii suscetível e resistente ao inseticida carbosulfam}

Este estudo foi realizado em condições de estufa no campo experimental do Setor de Entomologia da ESALQ/USP, Piracicaba-SP. Os inseticidas carbosulfam (Marshal 400 SC), tiametoxam (Actara 250 WG) e endosulfam (Thiodan CE) foram utilizados nas doses recomendadas pelos fabricantes. Os tratamentos e as respectivas concentrações estão descritos no Quadro 5.

As plantas de algodão utilizadas nesse experimento foram cultivadas em vasos de 1 litro de volume, sendo que em cada vaso foram mantidas duas plantas tutoradas por uma estaca de bambu. As plantas foram pulverizadas aos 45 dias após a germinação. As pulverizações dos tratamentos foram realizadas na parte externa da estufa e posteriormente, os vasos, foram acondicionados no interior da estufa.

Para uma melhor uniformidade de cobertura, a aplicação foi realizada com pulverizador pressurizado com gás carbônico. O equipamento foi calibrado para uma pulverização média de 100 L/ha. O tratamento testemunha foi pulverizado apenas com água. Foi utilizado delineamento estatístico inteiramente casualizado.

Após a aplicação, as folhas foram coletadas periodicamente para a avaliação da atividade biológica dos resíduos sobre as linhagens de A. gossypii suscetível e resistente ao inseticida carbosulfam. As coletas foram efetuadas imediatamente após a aplicação e no $1^{\underline{0}}, 3^{0}, 5^{\underline{0}}, 7^{\underline{0}}, 14^{\circ}$ e $20^{\circ}$ dia após a aplicação. Em cada tratamento foram coletadas cinco folhas, sendo que de cada folha foram retirados dois discos, um para teste com a linhagem resistente e outra para a suscetível. Cada tratamento foi repetido cinco vezes sendo que cada repetição foi constituída de 40 pulgões $\mathrm{O}$ procedimento de bioensaio utilizado foi o mesmo descrito anteriormente, porém a mortalidade foi avaliada após 48 horas. As 
médias de mortalidade $(P)$ de cada tratamento foram transformados em arc sen ( $\sqrt{P / 100})$ e submetidos à análise de variância, ao nível de significância de $\alpha=0,05$.

\begin{tabular}{|lcc|}
\hline Tratamento & $\begin{array}{c}\text { Dose } \\
\text { (g de I.A./ha) }\end{array}$ & $\begin{array}{c}\text { Concentração } \\
\text { (mg de I.A./L) }\end{array}$ \\
\hline Carbosulfam & $120 \mathrm{~g}$ & 1.200 \\
Tiametoxam & $25 \mathrm{~g}$ & 250 \\
Endosulfam & $350 \mathrm{~g}$ & 3.500 \\
Carbosulfam +tiametoxam & $120 \mathrm{~g}+25 \mathrm{~g}$ & $1.200+250$ \\
Carbosulfam + endosulfam & $120 \mathrm{~g}+350 \mathrm{~g}$ & $1.200+3.500$ \\
Tiametoxam + endosulfam & $25 \mathrm{~g}+350 \mathrm{~g}$ & $250+3.500$ \\
\hline
\end{tabular}

Quadro 5- Tratamentos utilizados e suas respectivas doses e concentrações para a avaliação da mistura de inseticidas no manejo da resistência de Aphis gossypii ao carbosulfam 


\section{RESULTADOS E DISCUSSÃO}

\subsection{Caracterização das linhas-básicas de suscetibilidade de Aphis gossypii a inseticidas}

A caracterização das linhas-básicas de suscetibilidade da linhagem suscetível de A. gossypii aos inseticidas carbosulfam, tiametoxam e endosulfam bem como as respectivas concentrações diagnósticas (baseadas nas $\mathrm{CL}_{95}$ de cada produto) estão representadas na Tabela 1.

Para a caracterização da linha-básica de suscetibilidade de A. gossypii ao inseticida carbosulfam foram testados 833 pulgões. A CL s0 $_{50}$ estimada foi de 9,40 mg de carbosulfam/L de água (I.C. 95\% 4,43 - 8,10) e coeficiente angular ( \pm erro

padrão) de 3,05 $\pm(0,19), \chi^{2}$ de 6,91 (graus de liberdade $\left.=3, P>0,05\right)$ e heterogeneidade de 2,30. A concentração diagnóstica definida para o monitoramento foi de $32 \mathrm{mg}$ de carbosulfam/L de água.

Para a caracterização da linha-básica da suscetibilidade de A. gossypii ao tiametoxam foram utilizados 872 pulgões. A $\mathrm{CL}_{50}$ estimada foi de $4,61 \mathrm{mg}$ de tiametoxam/L de água (I.C. 95\% 3,23 - 5,98) e coeficiente angular ( \pm erro padrão) de 2,24 ( $\pm 0,19$ ), $\chi^{2}$ de 6,62 (graus de liberdade $=3, P>0,05$ ) e heterogeneidade de 2,21. A concentração diagnóstica definida para o monitoramento foi de $25 \mathrm{mg}$ de tiametoxam/L de água. 
Para a caracterização da linha-básica da suscetibilidade de A. gossypii ao endosulfam foram utilizados 884 pulgões. A CL $\mathrm{CL}_{50}$ estimada foi de 234,91 mg de endosulfam/L de água (I.C. 95\% 208,58 - 264,79) e coeficiente angular ( \pm erro padrão) de 5,03 ( $\pm 0,28), \chi^{2}$ de 10,25 (graus de liberdade $=3, P>0,05$ ) e heterogeneidade de 3,42. A concentração diagnóstica definida para o monitoramento foi de $500 \mathrm{mg}$ de endosulfam/L.

A utilização de concentrações diagnósticas ou discriminatórias em programas de monitoramento da resistência foi abordada por (Roush \& Miller, 1986). Através da utilização dessas concentrações é possível determinar a problemática da resistência através da avaliação da freqüência de resistência de $A$. gossypii aos diferentes inseticidas.

Tabela 1. Caracterização das linhas-básicas de suscetibilidade da linhagem suscetível de Aphis gossypii aos inseticidas carbosulfam, tiametoxam e endosulfam e respectivas concentrações diagnósticas

\begin{tabular}{lcccc}
\hline Inseticida & $\boldsymbol{n}^{*}$ & $\begin{array}{c}\text { Coef. angular } \\
\mathbf{\pm} \text { erro padrão }\end{array}$ & $\begin{array}{c}\mathbf{C L}_{\mathbf{5 0}}(\mathbf{m g} \text { de I.A./ L) } \\
\mathbf{( 9 5} \mathbf{\%} \text { I.C. })\end{array}$ & $\begin{array}{c}\text { Concentração } \\
\text { diagnóstica (mg } \\
\text { de I.A./L) }\end{array}$ \\
\hline Carbosulfam & 833 & $3,04 \pm 0,19$ & 9,40 & 32 \\
Tiametoxam & 872 & $1,89 \pm 0,11$ & $\begin{array}{c}(4,43-8,10) \\
(3,23-5,98)\end{array}$ & 25 \\
Endosulfam & 884 & $4,15 \pm 0,24$ & 234,91 & 500 \\
& & & $(208,58-264,79)$ & \\
\hline
\end{tabular}

* número de pulgões testados 


\subsection{Monitoramento da suscetibilidade de Aphis gossypii a inseticidas}

O monitoramento da suscetibilidade de A. gossypii aos inseticidas carbosulfam, tiametoxam e endosulfam, foi realizado por meio das concentrações diagnósticas previamente estabelecidas para os respectivos inseticidas. Os resultados mostraram que não ocorreram alterações significativas na suscetibilidade, aos inseticidas tiametoxam e endosulfam ente as diferentes populações de A. gossypii coletadas ao longo do ciclo da cultura do algodão das safras 2001/2002 a 2003/3004 nas regiões de produtoras de Acreúna-GO, Ituverava-SP, Rondonópolis-MT e Unai-MG (Tabelas 3, 4 e Figuras 2 e 3). Porém, para o inseticida carbosulfam foram observadas alterações significativas na suscetibilidade entre populações de A. gossypii (Tabela 2 e Figuras 1).

Para o inseticida carbosulfam, o monitoramento por meio do uso da concentração diagnóstica de $32 \mathrm{mg}$ de carbosulfam/L mostrou que as populações de A. gossypii coletadas ao longo da cultura do algodão em cada safra nas três regiões apresentaram alterações na suscetibilidade (Tabela 2 e Figura 1). Em algumas safras e em todas regiões houve uma redução na suscetibilidade nas populações provenientes da segunda e/ou terceira coletadas, quando comparada com a primeira coleta.

Nas safras 2001/2002 e 2002/2003 todas regiões avaliadas utilizaram cultivares resistentes a viroses e dessa forma, A. gossypii não exigiu um controle rígido por meio da utilização de inseticidas, sendo que no período, o número de aplicações de carbosulfam variou de 2 a 3 vezes. Apesar da utilização de cultivares resistentes a viroses, há necessidade de se preocupar com o manejo da resistência de A. gossypii ao carbosulfam, principalmente em algumas regiões como Acreúna-GO e Rondonópolis-MT que apresentaram sobrevivências médias superiores a 10 \% na concentração diagnóstica. 
Na safra 2001/2002 somente na região de Acreúna-GO foi possível realizar três coletas e o monitoramento da suscetibilidade ao carbosulfam mostrou que na primeira coleta (5 \% de sobreviventes) e na segunda coleta (8,5 \% de sobreviventes), as sobrevivências médias observadas na concentração diagnóstica testada foram estatisticamente iguais; porém, na terceira coleta foi observada uma redução significativa na suscetibilidade (10 \% de sobreviventes). Nesta mesma safra, nas demais regiões foi possível apenas a realização de 2 coletas. Neste caso, houve diferenças significativas na suscetibilidade apenas para as populações coletadas em Rondonópolis-MT. Nessa região, a primeira população coletada apresentou uma sobrevivência média de 7,5 \% já a segunda população apresentou uma sobrevivência média de 15 \% (após três aplicações de carbosulfam). Nas regiões de Ituverava-SP e Unai-MG, as populações provenientes da primeira e segunda coleta não apresentaram diferenças significativas quanto à suscetibilidade ao carbosulfam.

Na safra 2003/2004 foram utilizadas cultivares suscetíveis a visores (Faber Max-966) nas regiões de Acreúna-GO e Rondonópolis-MT e dessa forma, os produtores tiveram um cuidado maior com o controle do pulgão. O número de aplicações de carbosulfam variou de 4 a 5 vezes durante a safra. Apesar da utilização de cultivares resistentes a viroses nas regiões de Ituverava-SP e UnaiMG, a boa perspectiva de preços fez com que os produtores também adotassem um controle mais rígido da praga e, realizaram de 3 a 4 pulverizações com carbosulfam durante o ciclo da cultura. Nessa safra, foi possível a coleta das três populações ao longo do ciclo da cultura em toda as regiões. Portanto, a redução da suscetibilidade ao carbosulfam em populações de $A$. gossypii ao longo do ciclo da cultura foi significativa.

Na safra 2003/2004, em todas as regiões as populações provenientes da segunda e/ou terceira coletas mostraram-se menos suscetíveis quando comparadas à população proveniente da primeira coleta. Esses dados evidenciam que 
realmente há uma relação entre uso do inseticida carbosulfam e a redução na suscetibilidade de algumas populações de A. gossypii provenientes de certas regiões. Em algumas regiões, o aumento da dose de carbosulfam nas pulverizações realizadas no final do ciclo tem sido uma prática comum para aumentar a eficiência de controle do pulgão. Essa prática embora comum é totalmente inadequada, uma vez que pode intensificar a magnitude do problema da resistência.

Em relação às diferentes safras, houve o restabelecimento da suscetibilidade ao carbosulfam na safra seguinte. Isto é, durante a safra ocorre um aumento da freqüência de sobrevivência ao carbosulfam em função da alta pressão de seleção exercida por esse inseticida. Porém, a suscetibilidade ao carbosulfam, no início da safra subseqüente foi sempre maior quando comparado à suscetibilidade da segunda ou terceira populações provenientes das safras anteriores. Essa observação fornece um indicativo de que a resistência ao carbosulfam em populações de A. gossypii foi instável e essa instabilidade pode ser explorada em um programa de manejo da resistência.

Em relação aos inseticidas tiametoxam e endosulfam, não houve diferenças significativas quanto à suscetibilidade das diversas populações coletadas durante o ciclo da cultura nas diferentes regiões produtora nas três safras (Tabelas 3 e 4 e Figuras 2 e 3). Em relação ao inseticida tiametoxam, nem todos os produtores utilizaram esse produto. O tiametoxam foi aplicado apenas uma vez por safra em algumas regiões. A baixa pressão de seleção exercida com esse inseticida é, sem dúvida alguma, o fator determinante para a manutenção da eficiência desse produto. 
Tabela 2. Sobrevivência média (\%) ( \pm erro padrão da média) de populações de Aphis gossypii coletadas em diferentes épocas do ciclo da cultura do algodão nas regiões de Acreúna-GO, Ituverava-SP, Rondonópolis-MT e Unai-MG, submetida à concentração diagnóstica de $32 \mathrm{mg}$ de carbosulfam/L de água

\begin{tabular}{|c|c|c|c|c|}
\hline \multirow[b]{2}{*}{ Região } & \multirow[b]{2}{*}{ Coleta } & \multicolumn{3}{|c|}{ Safra } \\
\hline & & $2001 / 2002$ & $2002 / 2003$ & 2003/2004 \\
\hline \multirow[t]{3}{*}{ Acreúna-GO } & 1 & $5,0( \pm 0,500) \mathrm{a}$ & $4,5( \pm 0,551) \mathrm{a}$ & $4,0( \pm 1,155) \mathrm{a}$ \\
\hline & 2 & $8,5( \pm 0,957)$ a & $9,5( \pm 0,979) \mathrm{b}$ & $12,0( \pm 0,816) b$ \\
\hline & 3 & $10,5( \pm 0,512) b$ & --- & $14,5( \pm 2,217) b$ \\
\hline$P$ & & 0,0012 & 0,0036 & 0,0023 \\
\hline$F$ & & 15,50 & 21,43 & 12,94 \\
\hline Graus de liberdade & & 2,9 & 1,6 & 2,9 \\
\hline \multirow[t]{3}{*}{ Ituverava-SP } & 1 & $5,0( \pm 0,577) \mathrm{a}$ & $7,5( \pm 0,564)$ a & $9,5( \pm 0,957) \mathrm{a}$ \\
\hline & 2 & $6,5( \pm 0,500)$ a & $6,5( \pm 1,258)$ a & $14,5( \pm 1,258) b$ \\
\hline & 3 & --- & --- & $15,5( \pm 0,957) b$ \\
\hline$P$ & & 0,0972 & 0,4881 & 0,0070 \\
\hline$F$ & & 3,86 & 0,55 & 9,07 \\
\hline Graus de liberdade & & 1,6 & 1,6 & 2,9 \\
\hline \multirow[t]{3}{*}{ Rondonópolis-MT } & 1 & $7,5( \pm 0,500) \mathrm{a}$ & $8,0( \pm 0,816)$ a & $7,0( \pm 1,290) \mathrm{a}$ \\
\hline & 2 & $15,0( \pm 0,567) b$ & $8,5( \pm 0,500)$ a & $14,5( \pm 1,708) b$ \\
\hline & 3 & --- & --- & $15,5( \pm 0,935) b$ \\
\hline$P$ & & $<0,0001$ & 0,6202 & 0,0031 \\
\hline$F$ & & 96,43 & 0,27 & 11,17 \\
\hline Graus de liberdade & & 1,6 & 1,6 & 2,9 \\
\hline \multirow[t]{3}{*}{ Unai - MG } & 1 & $2,5( \pm 0,957)$ a & $5,0( \pm 1,000)$ a & $6,0( \pm 0,852) \mathrm{a}$ \\
\hline & 2 & $3,5( \pm 0,893)$ a & $8,0( \pm 1,414)$ a & $7,5( \pm 1,708)$ a \\
\hline & 3 & --- & --- & $14( \pm 0,824) b$ \\
\hline$P$ & & 0,4881 & 0,1340 & 0,0024 \\
\hline$F$ & & 0,55 & 3,00 & 12,76 \\
\hline Graus de liberdade & & 1,6 & 1,6 & 2,9 \\
\hline
\end{tabular}

Médias seguidas de mesma letra, na coluna, não diferem estatisticamente entre si, pelo teste Tukey $(\alpha=0,05)$. 
Tabela 3. Sobrevivência média (\%) ( \pm erro padrão da média) de populações de Aphis gossypii coletadas em diferentes épocas do ciclo da cultura do algodão nas regiões de Acreúna-GO, Ituverava-SP, Rondonópolis-MT e Unai-MG, submetida à concentração diagnóstica de $25 \mathrm{mg}$ de tiametoxam/L de água

\begin{tabular}{|c|c|c|c|c|}
\hline \multirow[b]{2}{*}{ Região } & \multirow[b]{2}{*}{ Coleta } & \multicolumn{3}{|c|}{ Safra } \\
\hline & & $2001 / 2002$ & $2002 / 2003$ & $2003 / 2004$ \\
\hline \multirow[t]{3}{*}{ Acreúna-GO } & 1 & $4,0( \pm 0,816) \mathrm{a}$ & $4,0( \pm 0,005) \mathrm{a}$ & $5,5( \pm 1,258)$ \\
\hline & 2 & $5,5( \pm 0,957)$ a & $5,0( \pm 0,577)$ a & $7,0( \pm 0,572) \mathrm{c}$ \\
\hline & 3 & $5,0( \pm 1,291)$ a & --- & $6,5( \pm 0,500)$ a \\
\hline$P$ & & 0,6013 & 0,1340 & 0,4758 \\
\hline$F$ & & 0,54 & 3,0 & 0,81 \\
\hline Graus de liberdade & & 2,9 & 1,6 & 2,9 \\
\hline \multirow[t]{3}{*}{ Ituverava-SP } & 1 & $3,5( \pm 0,957)$ a & $5,5( \pm 0,962)$ a & $6,5( \pm 1,500)$ a \\
\hline & 2 & $5,0( \pm 1,732)$ a & $4,5( \pm 0,500)$ a & $5,5( \pm 1,258)$ a \\
\hline & 3 & --- & --- & $6,0( \pm 0,816) \mathrm{c}$ \\
\hline$P$ & & 0,4772 & 0,3093 & 0,8490 \\
\hline$F$ & & 0,57 & 0,86 & 0,17 \\
\hline Graus de liberdade & & 1,6 & 1,6 & 2,9 \\
\hline \multirow[t]{3}{*}{ Rondonópolis-MT } & 1 & $4,5( \pm 0,957)$ a & $6,5( \pm 1,708)$ a & $5,5( \pm 1,893) a$ \\
\hline & 2 & $6,0( \pm 0,816)$ a & $5,0( \pm 0,577)$ a & $6,5( \pm 0,957)$ a \\
\hline & 3 & --- & --- & $6,5( \pm 1,500) \mathrm{c}$ \\
\hline$P$ & & 0,2782 & 0,4672 & 0,8644 \\
\hline$F$ & & 1,42 & 0,69 & 0,15 \\
\hline Graus de liberdade & & 1,6 & 1,6 & 2,9 \\
\hline \multirow[t]{3}{*}{ Unai - MG } & 1 & $4,5( \pm 1,258) \mathrm{a}$ & $5,0( \pm 1,291)$ a & $5,5( \pm 1,258)$ a \\
\hline & 2 & $4,5( \pm 0,957)$ a & $5,5( \pm 1,708)$ a & $6,0( \pm 1,414) \mathrm{c}$ \\
\hline & 3 & --- & --- & $6,5( \pm 1,500) \mathrm{c}$ \\
\hline$P$ & & 1,0000 & 0,8231 & 0,8809 \\
\hline$F$ & & 0,00 & 0,05 & 0,13 \\
\hline Graus de liberdade & & 1,6 & 1,6 & 2,9 \\
\hline
\end{tabular}

Médias seguidas de mesma letra, na coluna, não diferem estatisticamente entre si, pelo teste Tukey $(\alpha=0,05)$. 
Tabela 4. Sobrevivência média (\%) ( \pm erro padrão da média) de populações de Aphis gossypii coletadas em diferentes épocas do ciclo da cultura do algodão nas regiões de Acreúna-GO, Ituverava-SP, Rondonópolis-MT e Unai-MG, submetida à concentração diagnóstica de 500 mg de endosulfam/L de água

\begin{tabular}{|c|c|c|c|c|}
\hline \multirow[b]{2}{*}{ Região } & \multirow[b]{2}{*}{ Coleta } & \multicolumn{3}{|c|}{ Safra } \\
\hline & & $2001 / 2002$ & $2002 / 2003$ & 2003/2004 \\
\hline \multirow[t]{3}{*}{ Acreúna-GO } & 1 & $5,0( \pm 0,577) \mathrm{a}$ & $4,0( \pm 0,816) \mathrm{a}$ & $5,0( \pm 1,291)$ \\
\hline & 2 & $5,5( \pm 1,893)$ a & $6,5( \pm 1,258) \mathrm{a}$ & $6,5( \pm 1,500) \mathrm{c}$ \\
\hline & 3 & $4,0( \pm 0,816) \mathrm{a}$ & --- & $5,5( \pm 0,500)$ \\
\hline$P$ & & 0,6932 & 0,1466 & 0,6693 \\
\hline$F$ & & 0,38 & 2,78 & 0,42 \\
\hline Graus de liberdade & & 2,9 & 1,6 & 2,9 \\
\hline \multirow[t]{3}{*}{ Ituverava-SP } & 1 & $5,5( \pm 0,500)$ a & $5,0( \pm 1,291)$ a & $6,5( \pm 0,957)$ a \\
\hline & 2 & $4,5( \pm 0,957)$ a & $5,5( \pm 0,957)$ а & $6,0( \pm 0,816)$ a \\
\hline & 3 & --- & --- & $6,5( \pm 0,500) \mathrm{c}$ \\
\hline$P$ & & 0,3903 & 0,7663 & 0,8743 \\
\hline$F$ & & 0,86 & 0,10 & 0,14 \\
\hline Graus de liberdade & & 1,6 & 1,6 & 2,9 \\
\hline \multirow[t]{3}{*}{ Rondonópolis-MT } & 1 & $6,5( \pm 0,963)$ a & $6,5( \pm 1,500)$ a & $6,0( \pm 1,826) \mathrm{c}$ \\
\hline & 2 & $6,0( \pm 1,414) \mathrm{a}$ & $5,5( \pm 0,957)$ a & $8,5( \pm 1,285) \mathrm{c}$ \\
\hline & 3 & --- & --- & $6,0( \pm 0,000) \mathrm{a}$ \\
\hline$P$ & & 0,7796 & 0,5945 & 0,3264 \\
\hline$F$ & & 0,09 & 0,32 & 1,27 \\
\hline Graus de liberdade & & 1,6 & 1,6 & 2,9 \\
\hline \multirow[t]{3}{*}{ Unai - MG } & 1 & $6,0( \pm 1,633)$ a & $4,5( \pm 0,963)$ a & $5,0( \pm 0,577)$ \\
\hline & 2 & $6,0( \pm 0,816)$ a & $6,0( \pm 1,633)$ a & $5,5( \pm 1,500)$ a \\
\hline & 3 & --- & --- & $5,0( \pm 1,291) \mathrm{c}$ \\
\hline$P$ & & 1,0000 & 0,4583 & 0,9432 \\
\hline$F$ & & 0,00 & 0,63 & 0,06 \\
\hline Graus de liberdade & & 1,6 & 1,6 & 2,9 \\
\hline
\end{tabular}

Médias seguidas de mesma letra, na coluna, não diferem estatisticamente entre si, pelo teste Tukey $(\alpha=0,05)$. 

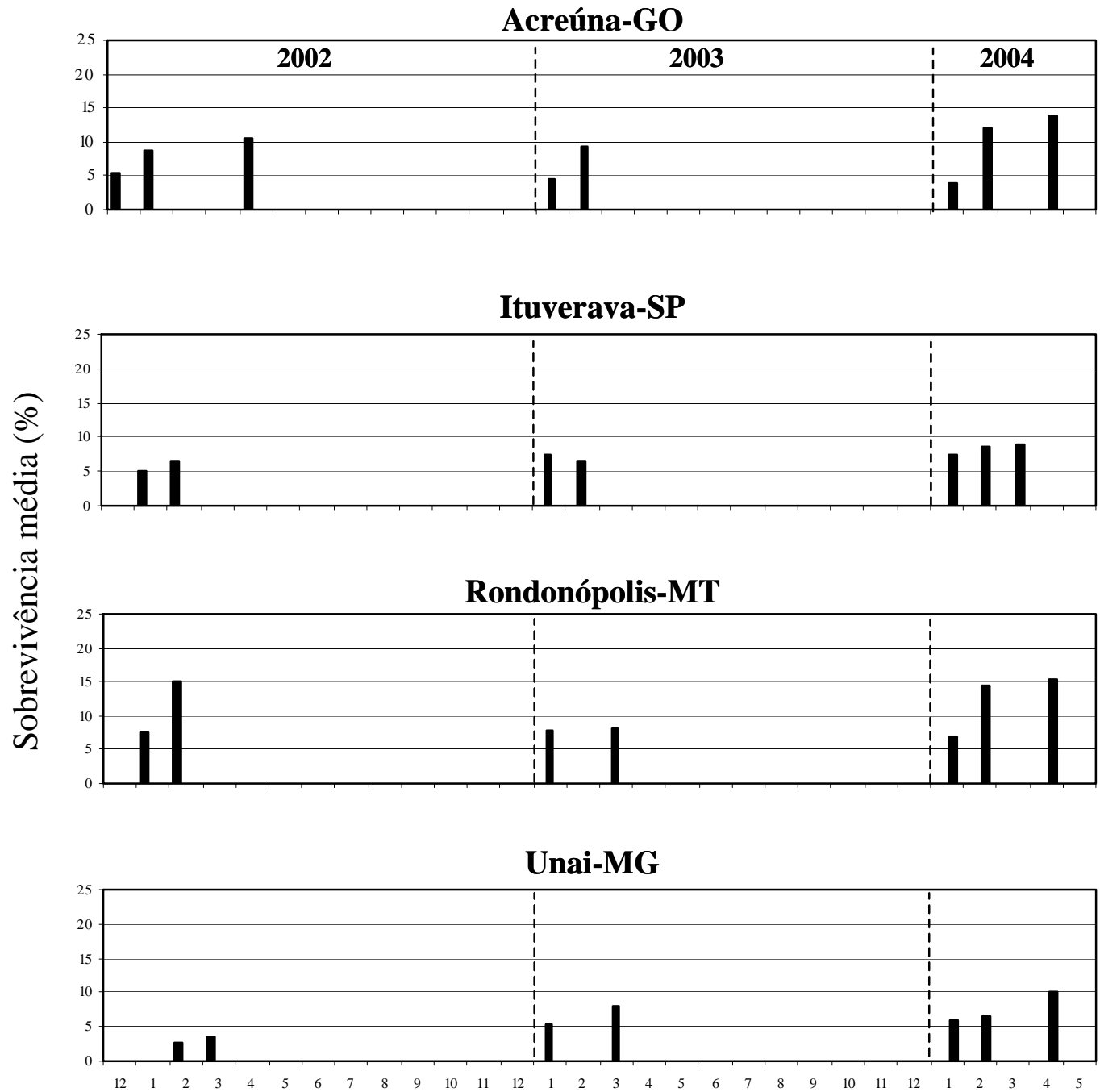

Tempo (meses)

Figura 1- Médias de sobrevivência de populações de Aphis gossypii coletadas em diferentes épocas do ciclo da cultura nas safras 2001/2002 a 2003/2004, submetidas à concentração diagnóstica de $32 \mathrm{mg}$ de carbosulfam/L de água 

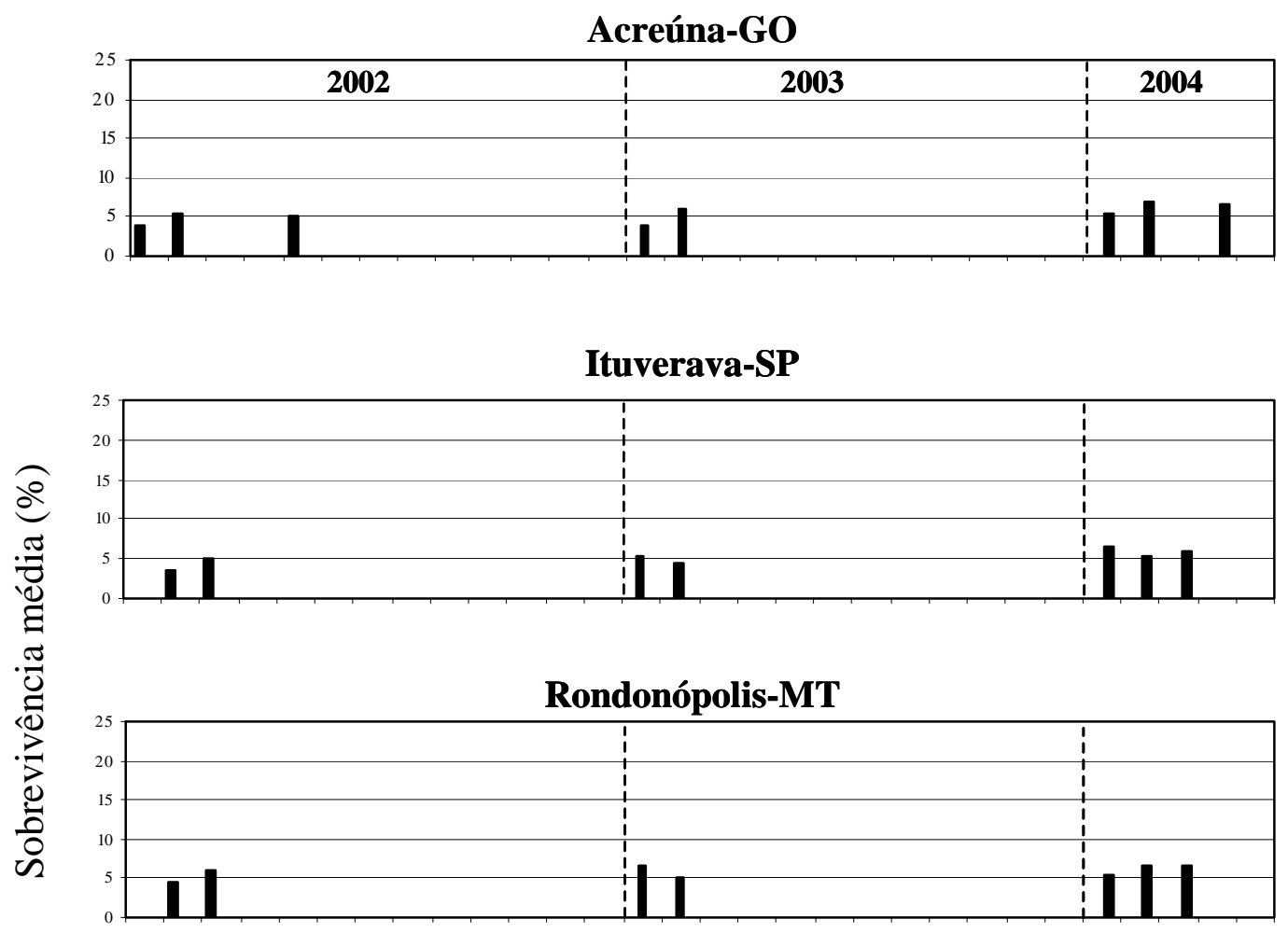

Unai-MG

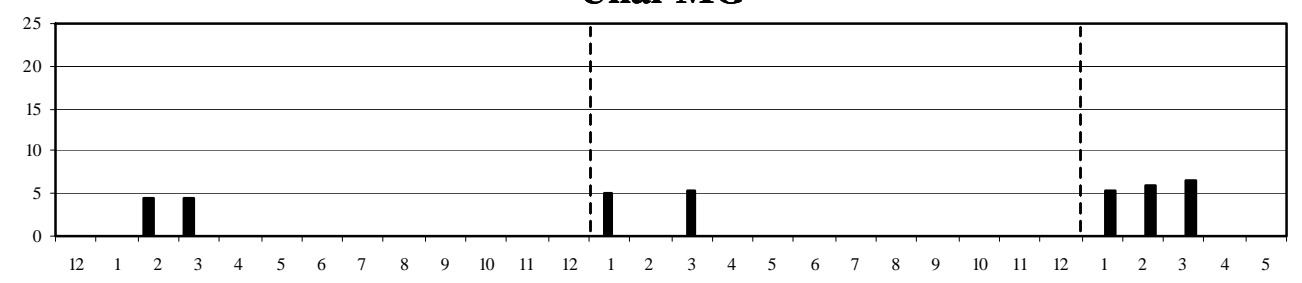

Tempo (meses)

Figura 2- Médias de sobrevivência de populações de Aphis gossypii coletadas em diferentes épocas do ciclo da cultura nas safras 2001/2002 a 2003/2004, submetidas à concentração diagnóstica de $25 \mathrm{mg}$ de tiametoxam/L de água 

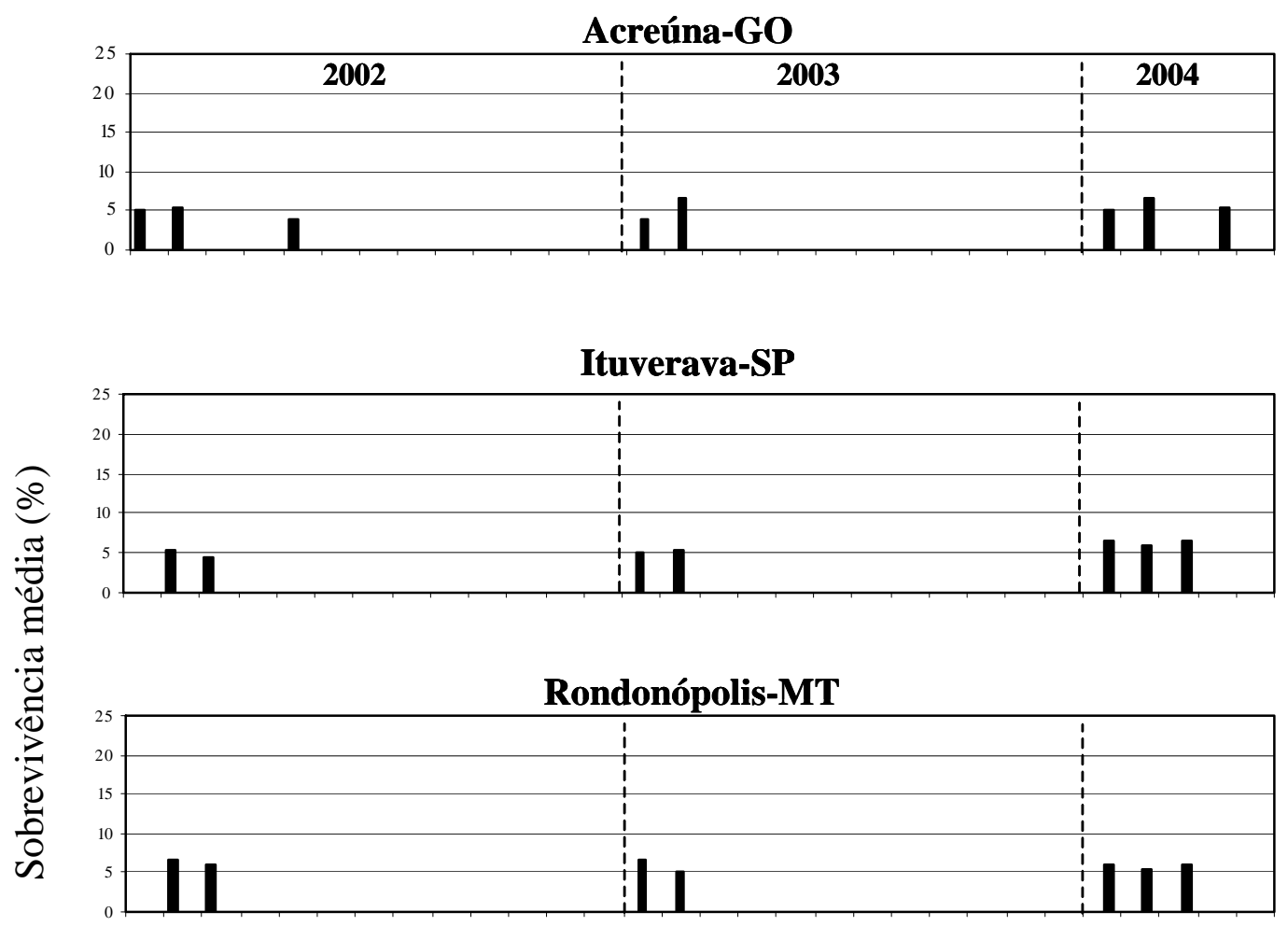

\section{Unai-MG}

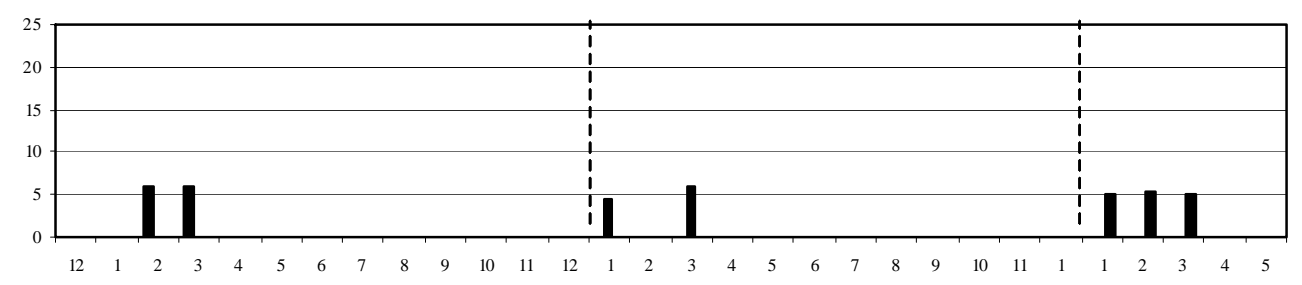

Tempo (meses)

Figura 3- Médias de sobrevivência de populações de Aphis gossypii coletadas em diferentes épocas do ciclo da cultura nas safras 2001/2002 a 2003/2004, submetidas à concentração diagnóstica de 500 mg de endosulfam /L de água 


\subsection{Isolamento e caracterização da resistência de Aphis gossypii ao inseticida carbosulfam}

A caracterização da linha-básica de suscetibilidade de Aphis gossypii ao inseticida carbosulfam foi reportada no item 4.1 (Tabela 1). Para a caracterização da resistência de A. gossypii ao carbosulfam foram utilizados 869 pulgões. A $\mathrm{CL}_{50}$ estimada para a linhagem resistente foi de 53,76 mg de carbosulfam/L de água (I.C. 95\% 45,55 - 63,32) e coeficiente angular ( \pm erro padrão) de 2,73 \pm (0,17), $\chi^{2}$ de 7,26 (graus de liberdade $=3, P>0,05$ ) e heterogeneidade de 2,42 . A razão de resistência encontrada foi de 5,7 vezes (IC 95\% 5,08 - 6,45) (Figura 4).

O teste de paralelismo e igualdade das linhas de concentração-resposta estimada pela análise de Probit mostrou que o coeficiente angular da linhagem suscetível $(3,71 \pm 0,23)$ foi significativamente maior que o da resistente $(2,73 \pm$ $0,17)\left(\chi^{2}=8,54\right.$, graus de liberdade $\left.=1, P<0,05\right)$. Segundo alguns autores, 0 coeficiente angular relaciona-se à homogeneidade da população (Hoskins \& Gordon, 1956) ou ao método de bioensaio utilizado na caracterização toxicológica (ffrench-Constant \& Roush, 1990). O método de bioensaio utilizado foi o mesmo para as duas populações dessa forma, o maior coeficiente angular da linhagem suscetível está provavelmente relacionado à sua maior homogeneidade.

No mais, houve uma sobreposição das linhas de concentração-resposta ao inseticida carbosulfam e dessa forma, não foi possível determinar uma concentração discriminatória. A concentração de $32 \mathrm{mg}$ de carbosulfam/L de água foi mantida como a concentração diagnóstica. Esta concentração ocasionou uma mortalidade de aproximadamente 95 \% na linhagem suscetível. 


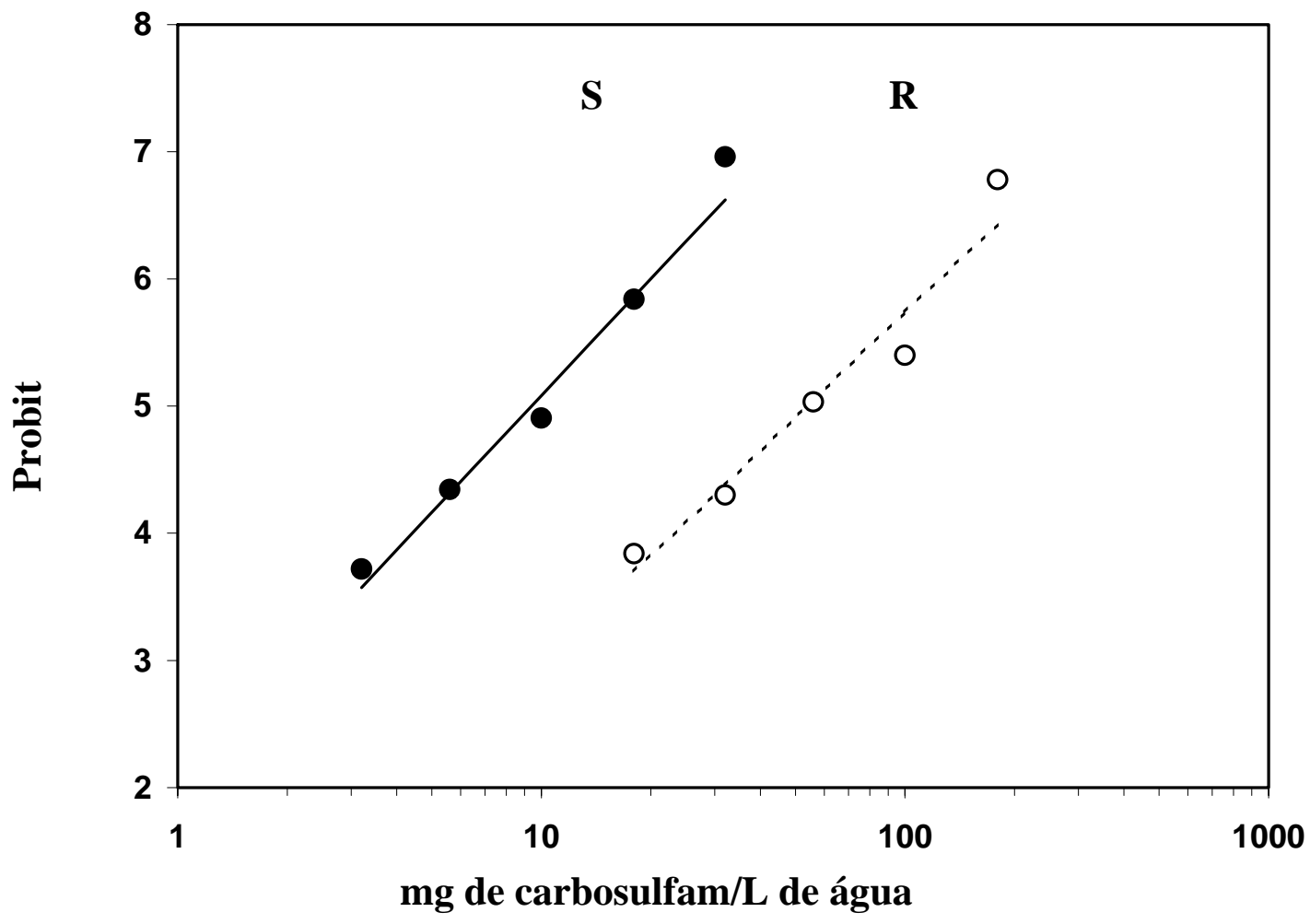

Figura 4- Linhas de concentração-resposta das linhagens de Aphis gossypii suscetível (S) e resistente (R) ao carbosulfam 


\subsection{Relações de resistência cruzada entre carbosulfam e os inseticidas tiametoxam e endosulfam}

O teste de paralelismo e igualdade das linhas de regressão estimada pela análise de Probit mostrou que as respostas das duas linhagens (suscetível e resistente ao carbosulfam) foram similares para os três inseticidas - tiametoxam $\left(\chi^{2}=3,80\right.$; graus de liberdade $\left.=1 ; P>0,05\right)$ endosulfam $\left(\chi^{2}=1,24\right.$; graus de liberdade $=1 ; P>0,05)$. Houve sobreposição dos intervalos de confiança das $\mathrm{CL}_{50}$ das linhagens suscetível e resistente para os dois inseticidas (Tabela 5 e Figuras 5 e 6).

Apesar de o presente trabalho não ter demonstrado a existência de resistência cruzada entre os inseticidas testados, a literatura tem demonstrado casos de resistência cruzada entre alguns inseticidas em pulgões.

Wang et al. (2002) estudaram as relações de resistência cruzada entre os inseticidas fenvalerate e imidacloprido em linhagens de A. gossypii provenientes das culturas de algodão e de pepino. As linhagens resistentes ao imidacloprido apresentaram resistência cruzada com o fenvalerate, com uma razão de resistência da ordem de 109 e 34 vezes para as linhagens provenientes das culturas de algodão e de pepino respectivamente. No entanto, não foi detectada a resistência cruzada entre fenvalerate e imidacloprido para as linhagens resistentes ao fenvalerate.

A resistência cruzada também foi verificada entre organofosforados e carbamatos em linhagens de Schizaphis graminum (Rondani) (Hemiptera: Aphididae) (Archer et al., 1994; Shufran, et al.,1997). Dessa forma, é importante determinar se o carbosulfam apresenta resistência cruzada com outros inseticidas comumente utilizados no controle de A. gossypii. Neste trabalho não foi verificada a presença de resistência cruzada entre o carbosulfam e os inseticidas tiametoxam e endosulfam. Dessa forma, os três inseticidas podem ser utilizados 
dentro de um contexto de manejo da resistência de $A$. gossypii ao inseticida carbosulfam.

Tabela 5. Concentração-resposta das linhagens de Aphis gossypii suscetível (S) e resistente (R) ao inseticida carbosulfam quando submetidas aos inseticidas tiametoxam e endosulfam

\begin{tabular}{|c|c|c|c|c|c|}
\hline Inseticida & Linhagem & $n^{1}$ & $\begin{array}{c}\mathrm{CL}_{50} \\
\text { (mg de I.A./L) } \\
\text { (95 \% I.C.) }\end{array}$ & $\begin{array}{l}\text { Coeficiente angular } \\
\pm \text { erro padrão }\end{array}$ & $\begin{array}{c}\text { Resistência } \\
\text { cruzada }\end{array}$ \\
\hline \multirow[t]{2}{*}{ Tiametoxam } & $S$ & 872 & $\begin{array}{c}4,61 \\
(3,23-5,98)\end{array}$ & $1,89 \pm 0,12$ & --- \\
\hline & $\mathrm{R}$ & 882 & $\begin{array}{c}4,46 \\
(3,51-5,66)\end{array}$ & $2,04 \pm 0,88$ & Ausente \\
\hline \multirow[t]{2}{*}{ Endosulfam } & S & 884 & $\begin{array}{c}234,91 \\
(208,5-264,7)\end{array}$ & $4,15 \pm 0,24$ & --- \\
\hline & $\mathrm{R}$ & 889 & $\begin{array}{c}265,00 \\
(246,7-287,3)\end{array}$ & $4,53 \pm 0,18$ & Ausente \\
\hline
\end{tabular}

${ }^{1} n$ = número de pulgões utilizados 


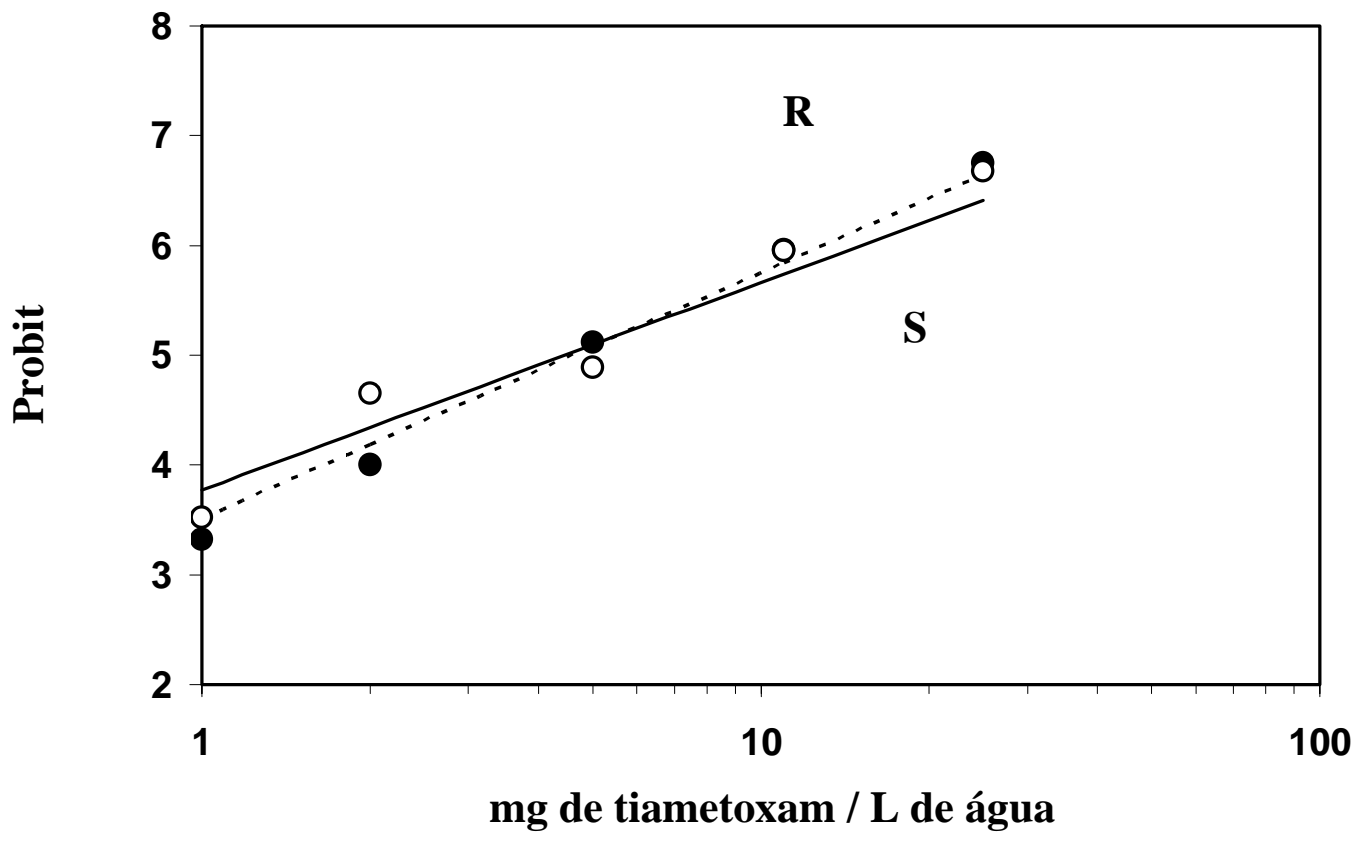

Figura 5- Linhas de concentração-resposta das linhagens de Aphis gossypii suscetível (S) e resistente (R) ao carbosulfam submetidas ao inseticida tiametoxam 


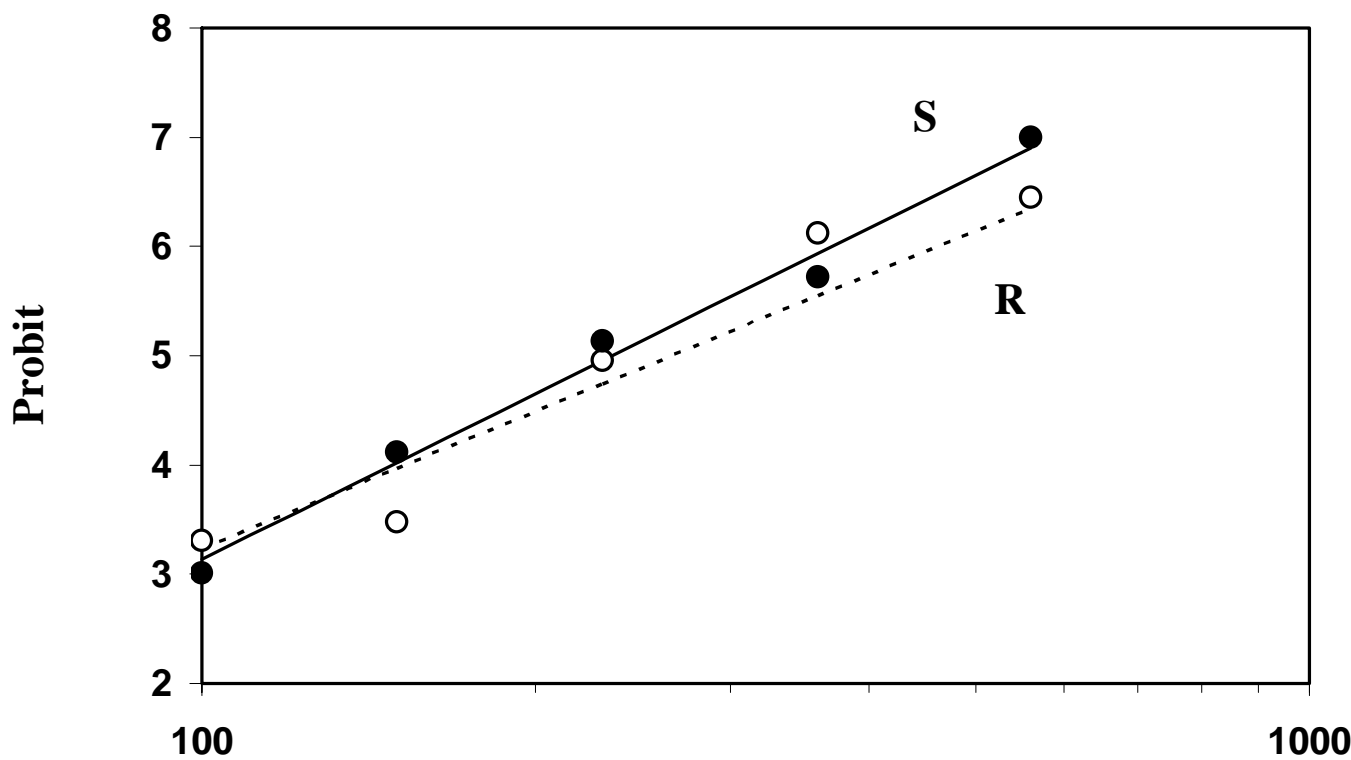

mg de endosulfam / $L$ de água

Figura 6- Linhas de concentração-resposta das linhagens de Aphis gossypii suscetível (S) e resistente (R) ao carbosulfam submetidas ao inseticida endosulfam 


\subsection{Dinâmica da resistência de Aphis gossypii ao inseticida carbosulfam em condições de laboratório}

As três populações de Aphis gossypii formadas a partir de distintas freqüências de resistência apresentaram reduções significativas na suscetibilidade ao carbosulfam na ausência de pressão seletiva em condições laboratoriais. As três populações estudadas apresentaram comportamentos distintos, ou seja, a interação da população e porcentagem de sobrevivência no decorrer do tempo foi significativa $(F=4,41$; graus de liberdade $=10,54 ; P=0,001)$ (Figura 7).

As maiores quedas nas porcentagens de sobrevivência foram observadas para as populações iniciais de 50 e $80 \%$ de indivíduos resistentes. Diferenças significativas foram observadas a partir do terceiro mês para as três populações.

As reduções nas porcentagens de sobrevivência observadas para as três populações indicam que a resistência de A. gossypii ao inseticida carbosulfam é instável na ausência de pressão seletiva com o respectivo inseticida. Essa redução não pode ser atribuída à contaminação por indivíduos suscetíveis como sugerido por Blackman et al. (1977) uma vez que o experimento foi conduzido em condições de isolamento das três populações.

Vários trabalhos têm mostrado que a resistência de pulgões a inseticidas é instável na ausência de pressão seletiva. Estudos realizados por Bauernfeind \& Chapman (1985) mostraram que a resistência de Myzus persicae aos inseticidas endosulfam e paratiom foi instável na ausência de pressão de seleção e a suscetibilidade era restabelecida após 10 - 27 gerações na ausência de pressão seletiva. A redução na freqüência de resistência também foi atribuída ao custo adaptativo dos indivíduos resistentes em A. gossypii (Foster et al., 2002) e Myzus persicae (Grafton-Cardwell, 1991). Por outro lado, Beranek (1974) mostrou que algumas populações de $M$. persicae resistente ao inseticida dimetoato se 
mantinham resistentes mesmos após várias gerações na ausência de pressão seletiva.

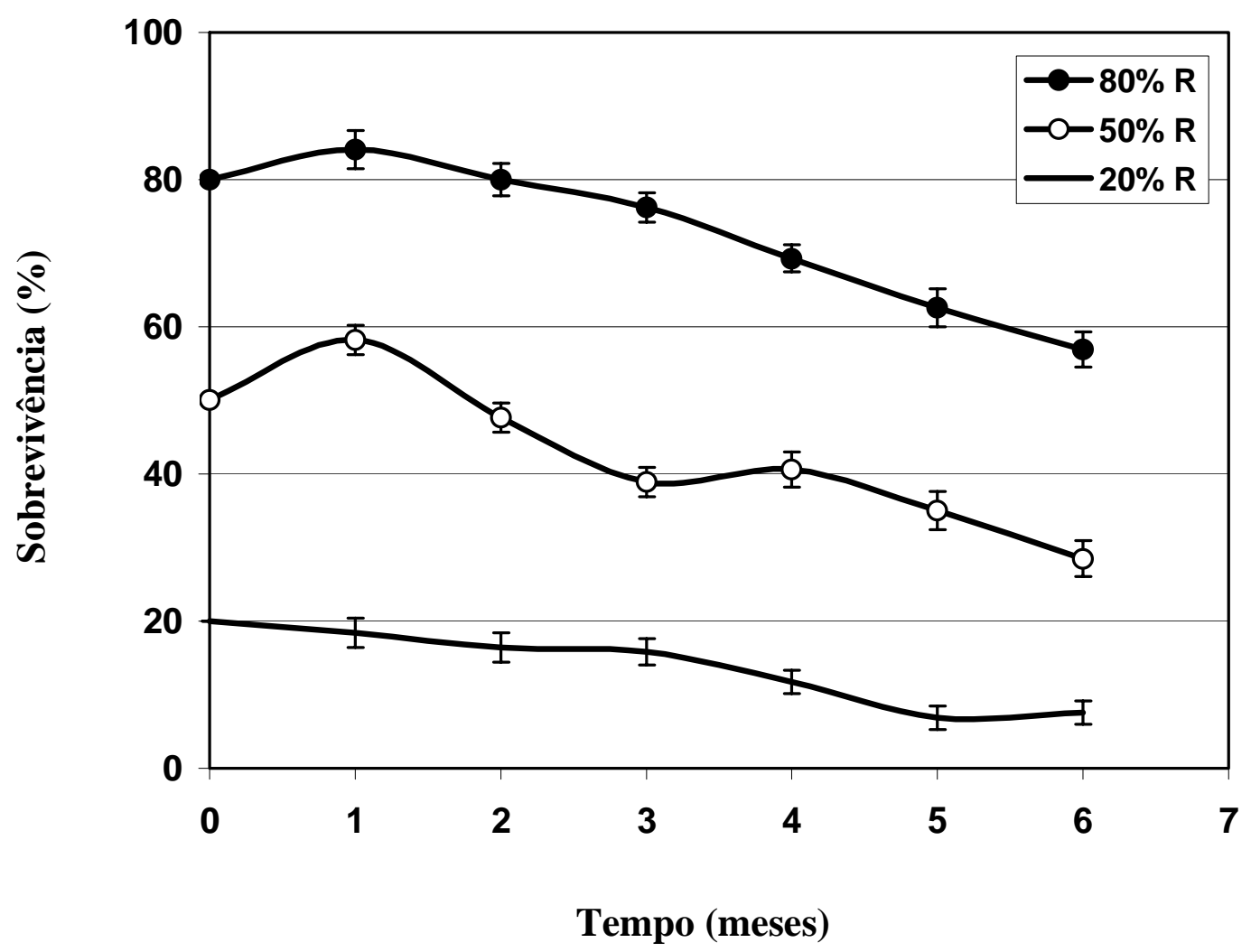

Figura 7- Alterações nas porcentagens de sobrevivência de Aphis gossypii ao inseticida carbosulfam em condições laboratoriais (temperatura de 25 $\pm 2^{\circ} \mathrm{C}$, UR de $60 \pm 10 \%$ e fotofase de 14 horas), submetidas à concentração diagnóstica de $32 \mathrm{mg}$ de carbosulfam/L de água 


\subsection{Biologia das linhagens de Aphis gossypii suscetível e resistente ao inseticida carbosulfam em condições de laboratório}

O estudo da biologia das linhagens resistente e suscetível de A. gossypii mostrou que existem diferenças significativas entre as linhagens para os parâmetros da fase adulta $(F=13,78$; graus de liberdade $=1,53 ; P=0,0005)$.

Não houve diferenças significativas no número de instares, no período ninfal e no período pré-reprodutivo (Tabela 6). A viabilidade ninfal foi de $100 \%$ para as duas linhagens.

Diferenças significativas foram observadas para os períodos reprodutivo, pós-reprodutivo e a longevidade (Tabela 6). A maior capacidade reprodutiva foi observada para a linhagem suscetível. O período reprodutivo da linhagem suscetível foi 1,63 vezes maior que a resistente e por sua vez a longevidade foi 1,53 vezes superior (Tabela 6 e Figura 8 e 9). Em relação ao número de descendentes, foi observada uma média de 48,04 e 14,96 ninfas por fêmea para a linhagem suscetível e resistente respectivamente, ou seja, o número de ninfas por fêmea da linhagem suscetível foi 3,21 superior ao da linhagem resistente. A linhagem resistente apresentou um período pós-reprodutivo 1,65 vezes superior à linhagem suscetível. Dessa forma, é possível afirmar que a instabilidade da resistência ao inseticida carbosulfam estava intimamente ligada aos parâmetros biológicos da fase adulta.

A partir dos dados obtidos no estudo da biologia foram elaboradas tabelas de vida e fertilidade para as duas linhagens (Tabela 7). Os parâmetros $R o, r_{m}$ e $\lambda$ indicaram que os pulgões da linhagem resistente apresentaram desvantagem reprodutiva em relação à linhagem suscetível na ausência de pressão seletiva. Um exemplo da desvantagem reprodutiva apresentada pela linhagem resistente pode ser observado a partir da sua menor taxa líquida de reprodução $(R o)$. O Ro da linhagem suscetível foi de 43,18 enquanto para a da resistente foi de apenas 
14,04. Isso significa que a linhagem suscetível tem uma capacidade de aumentar, a cada geração, 3,07 vezes a mais sua população quando comparada a linhagem resistente.

Trabalhos de custo adaptativo associado à resistência têm mostrado resultados bastante distintos. Stone et al. (2000) demonstraram que linhagens de Schizaphis graminum resistentes a pelo menos cinco inseticidas organofosforado apresentaram desvantagens reprodutivas - maior período pré-reprodutivio, menor produção de descendentes e menor razão finita de aumento $(\lambda)$. Pozarowska (1987) observou que não havia diferenças significativas nos parâmetros reprodutivos entre as linhagens de Myzus persicae resistente e suscetível a inseticidas organofosforados. Por outro lado, Eggers-Schumacher (1983) reportou que a linhagem de $M$. persicae resistente apresentou vantagens reprodutivas quando comparado à linhagem suscetível na ausência de pressão de seleção.

Muitas vezes, o custo adaptativo dos indivíduos resistentes pode estar relacionado a outros parâmetros biológicos, que não os parâmetros da tabela de vida e fertilidade. Foster et al., (1997) estudando a dispersão de M. persicae resistentes e suscetíveis, observaram que os indivíduos resistentes apresentavam uma menor mobilidade, isto é, os pulgões resistentes se mantinham por mais tempo nas folhas velhas das plantas. Este fato, torna os pulgões resistentes mais vulneráveis a se destacarem da planta, em função da queda da folha senil, podendo ocasionar suas morte por falta de alimento e proteção. 
Tabela 6. Duração média (em dias) dos diferentes períodos de desenvolvimento das linhagens de Aphis gossypii suscetível e resistente ao inseticida carbosulfam

\begin{tabular}{lcccccc}
\hline $\begin{array}{l}\text { Período } \\
\text { caraterística }\end{array}$ & $\boldsymbol{n}$ & Suscetível & & $\boldsymbol{n}$ & Resistente & \\
\hline Ninfal & 27 & 5,30 & A & 27 & 5,69 & A \\
Pré-reprodutivo & 27 & 0,43 & A & 27 & 0,33 & A \\
Reprodutivo & 26 & 16,36 & A & 27 & 10,00 & B \\
Pós-reprodutivo & 26 & 0,65 & A & 27 & 1,07 & B \\
Longevidade & 26 & 17,44 & A & 27 & 11,40 & B \\
\hline
\end{tabular}

$n$ = Número de observações

médias da mesma linha seguida por mesma letra não diferem estatisticamente pelo teste $F(P<0,05)$

Tabela 7. Parâmetros biológicos obtidos por meio da tabela de vida e fertilidade para as linhagens de Aphis gossypii suscetível e resistente ao inseticida carbosulfam, onde: duração média (dias) de uma geração $(T)$, taxa liquida de reprodução $(R o)$, capacidade inata de aumentar em número $\left(r_{m}\right)$ e razão finita de aumento $(\lambda)$

\begin{tabular}{ccc}
\hline Parâmetros biológicos & & Linhagens \\
\hline$T$ & Suscetível & Resistente \\
\hline Ro & 14,65 & 12,13 \\
$r_{m}$ & 43,18 & 14,04 \\
$\lambda$ & 0,26 & 0,22 \\
\hline
\end{tabular}




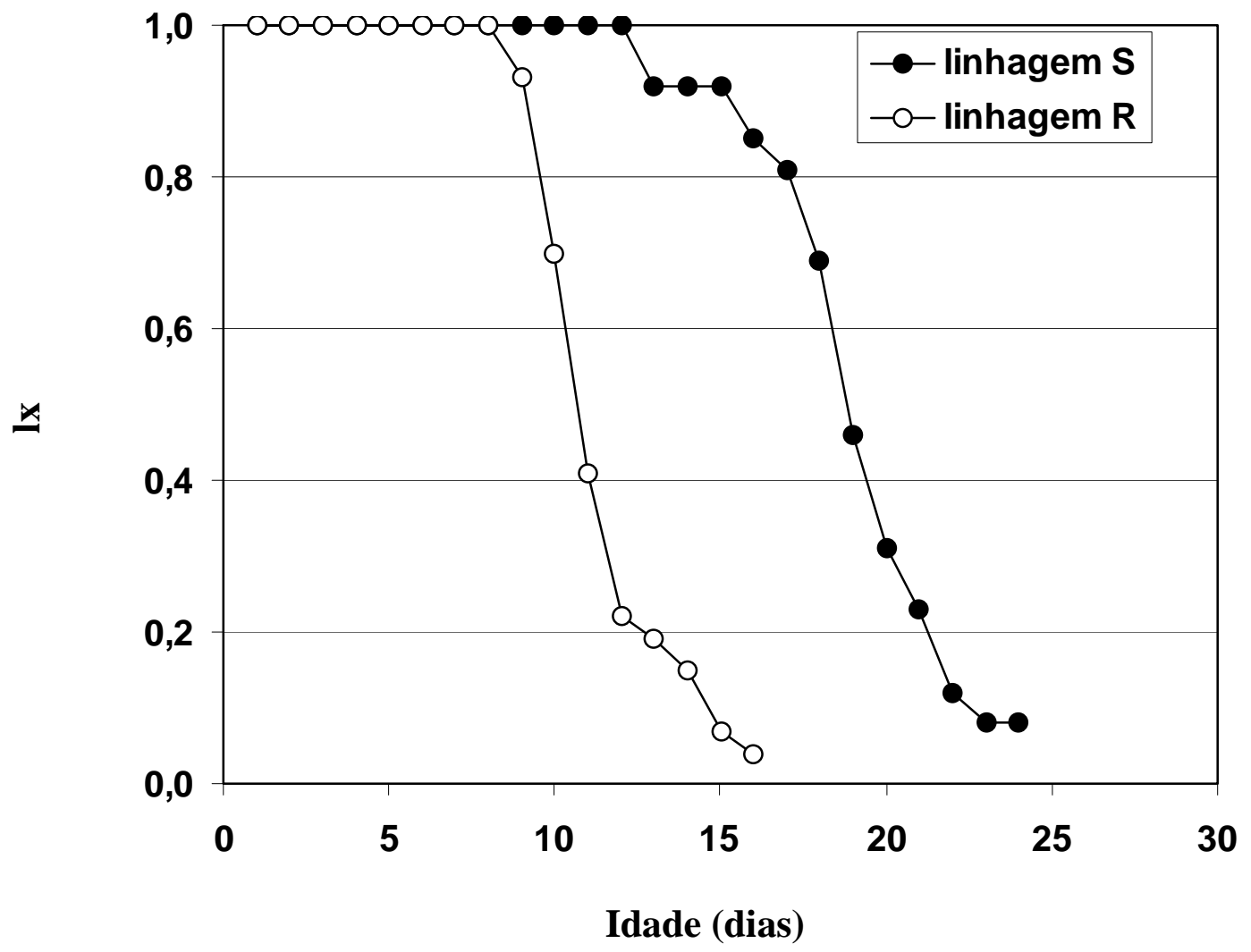

Figua 8- Sobrevivência de fêmeas (lx) das linhagens de Aphis gossypii suscetível (S) e resistente $(\mathrm{R})$ ao inseticida carbosulfam em condições laboratoriais 


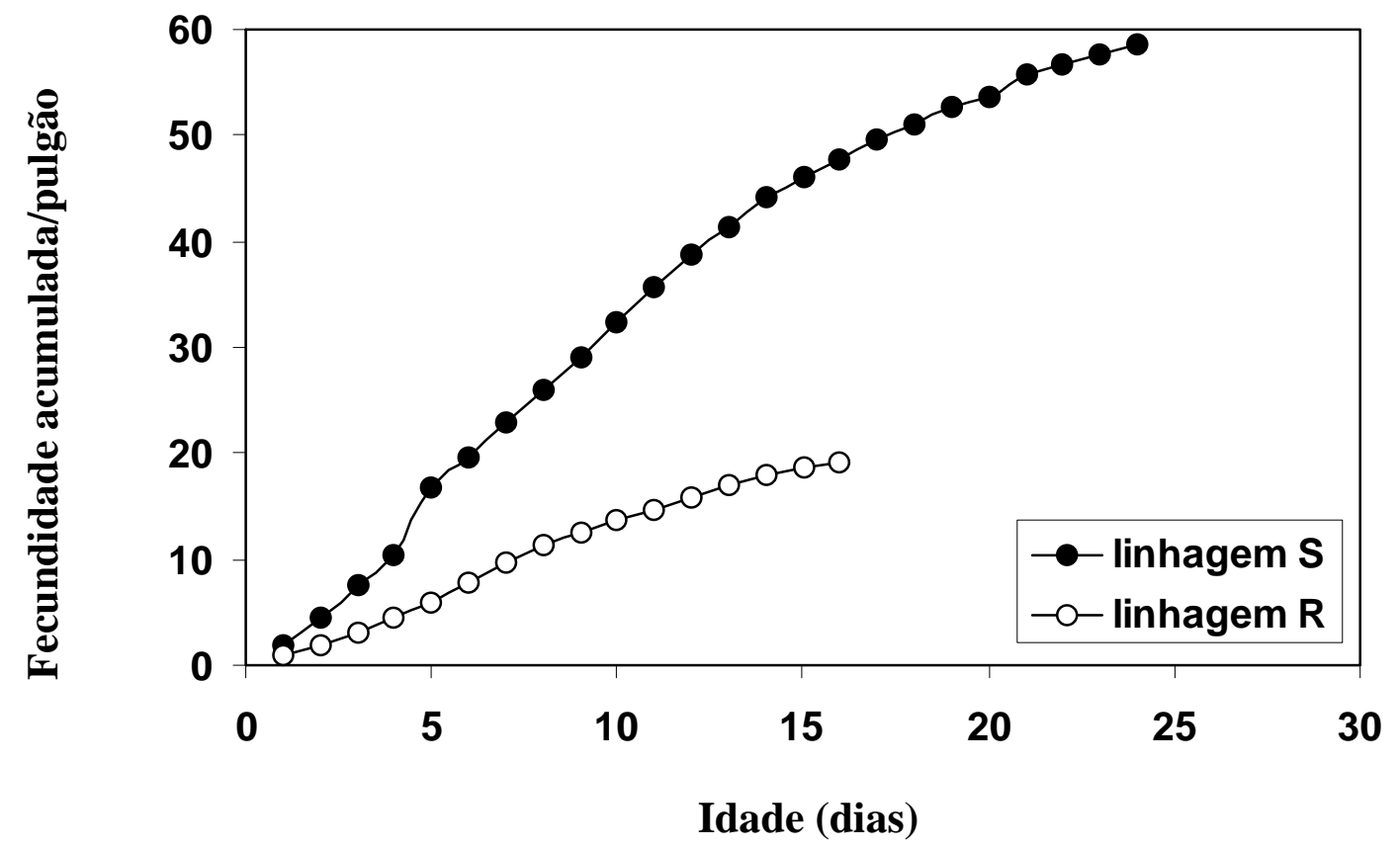

Figura 9- Fecundidade acumulada das linhagens de Aphis gossypii suscetível (S) e resistente (R) ao inseticida carbosulfam em condições laboratoriais 


\subsection{Efeito de mistura de inseticidas e dos produtos isolados sobre as linhagens de Aphis gossypii suscetível e resistente ao inseticida carbosulfam}

Tratamento carbosulfam: as duas linhagens se comportaram de forma distinta, isto é, houve um efeito significativo da linhagem no tratamento carbosulfam $(F=$ 24,78; graus de liberdade $=1,6 ; P=0,0053$ ). Os resíduos de 0,1 e 3 dias não permitiram a discriminação das linhagens suscetível e resistente. Por outro lado, os resíduos de 5 dias $(F=14,40$; graus de liberdade $=1,8 ; P=0,001), 7,(F=$ 54,73; graus de liberdade $=1,8 ; P>0,0001)$ e $14(F=32,52$; graus de liberdade $=1,8 ; P=0,001)$ permitiram a discriminação das duas linhagens. A atividade biológica dos resíduos de diferentes idades foi menos efetiva para a linhagem resistente, sendo que a discriminação ocorreu a partir do resíduo de 5 dias, sendo mais evidente nos resíduos de 7 e 14 dias (Figura 10).

Tratamento tiametoxam: as duas linhagens se comportaram de forma semelhante - não houve efeito significativo da linhagem $(F=0,40$; graus de liberdade $=1,6 ; P=0,529$ ) ou seja, as duas linhagens não foram discriminadas em momento algum. A redução da eficiência no controle das duas linhagens foi significativa nas diferentes idades do resíduo $(F=77,09$; graus de liberdade $=13$, 56; $P<0,001)$. O controle de $100 \%$ das duas linhagens foi observado apenas nos resíduos de 0 e 1 dia. $O$ resíduo de 7 dias proporcionou um controle superior a 80 \% nas duas linhagens o resíduo de 14 dias proporcionou uma mortalidade de 41,3 \% e 33,5 \% para as linhagens suscetível e resistente respectivamente (Figura 10).

Tratamento endosulfam: não houve efeito significativo da linhagem sobre o inseticida endosulfam ( $F=0,07$; graus de liberdade $=1,6 ; P=0,7878)$ ou seja, não houve discriminação entre as linhagens suscetível e resistente em momento 
algum. A redução da eficiência de controle das linhagens foi significativa no decorrer do tempo $(F=139,41$; graus de liberdade $=13$, 56; $P<0,001)$. Em nenhum momento o tratamento endosulfam proporcionou controle de $100 \%$ e a degradação do produto foi significativa ao longo do tempo. O resíduo de 0 dia ocasionou um controle de $97 \%$ e $93 \%$ das linhagens suscetível e resistente respectivamente. Aos 7 dias, o controle era de apenas $10 \%$ e $13 \%$ para as linhagens suscetível e resistente (Figura 10).

Tratamento carbosulfam + tiametoxam: as duas linhagens se comportaram de forma semelhante para a mistura de carbosulfam + tiametoxam, isto é, não houve efeito da linhagem na mistura $(F=0,55$; graus de liberdade $=1,6$; $P=0,461)$. A mistura não permitiu a discriminação das linhagens suscetível e resistente em nenhum momento. A degradação do resíduo foi significativa ao longo do tempo $(F=104,45$; graus de liberdade $=13,56 ; P<0,001)$. O resíduo de 7 dias proporcionou um controle de $87 \%$ e $80 \%$ para as linhagens suscetível e resistente respectivamente. $\mathrm{O}$ resíduo de 14 dias ocasionou um controle de apenas 58 \% e $44 \%$ para as linhagens suscetível e resistente (Figura 10).

Esse tratamento, apesar de não permitir a discriminação da linhagem resistente ao carbosulfam da suscetível, não segue uma das premissas básicas para a utilização da mistura que é a baixa freqüência de resistência aos dois componentes da mistura (Georghiou, 1983; Roush, 1989; Tabashnik, 1989). Por outro lado, os dois produtos apresentaram persistência semelhante quanto à atividade biológica. Dessa forma, sua utilização é passível em áreas onde a freqüência de resistência é baixa aos dois componentes da mistura. Porém, esta estratégia dever ser vista com cautela onde foi observada resistência para pelo menos um dos componentes da mistura. 
Tratamento carbosulfam + endosulfam: as duas linhagens se comportaram de forma distinta para essa mistura, isto é, houve efeito da linhagem para a mistura de carbosulfam + endosulfam $(F=14,94$; graus de liberdade $=1,6 ; P<0,001)$. A discriminação das linhagens suscetíveis e resistentes ocorreu apenas nos resíduos de 5 dias $(F=9,87$; graus de liberdade $=1,8 ; P=0,0138)$ e 7 dias $(F=10,27$; graus de liberdade $=1,8 ; P=0,125$ ) (Figura 10). Nesse tratamento, as duas premissas básicas para o uso da mistura não foram respeitadas: baixa freqüência resistência aos dois componentes da mistura e mesma persistência da atividade biológica (Georghiou, 1983; Roush, 1989; Tabashnik, 1989). Dessa forma, a mistura de carbosulfam + endosulfam não foi adequada para o manejo da resistência de A. gossypii ao inseticida carbosulfam.

Tratamento tiametoxam + endosulfam: a linhagem não apresentou efeito significativo nessa mistura $(F=0,54$; graus de liberdade $=1,6 ; P=0,467)$ ou seja, as linhagens suscetível e resistente não foram discriminadas por essa mistura. A redução da eficiência da mistura ao longo do experimento foi significativa $(F=85,63$; graus de liberdade $=13$, 56; $P<0,0001)$ (Figura 10). $\mathrm{O}$ resíduo de 7 dias proporcionou um controle superior a $85 \%$ para as duas linhagens. O resíduo de 14 dias proporcionou um controle de 60 \% e 42 \% para as linhagens suscetível e resistente respectivamente. A mistura de tiametoxam + endosulfam, apesar não ter discriminado a linhagem resistente ao carbosulfam, deve ser evitada uma vez que também não seque uma das condições básicas para o uso de mistura (mesma persistência). 
$120 \mathrm{~g}$ carbosulfam//ha

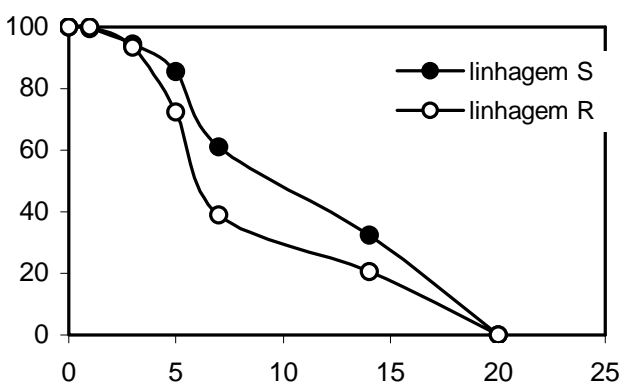

$350 \mathrm{~g}$ endosulfam/ha

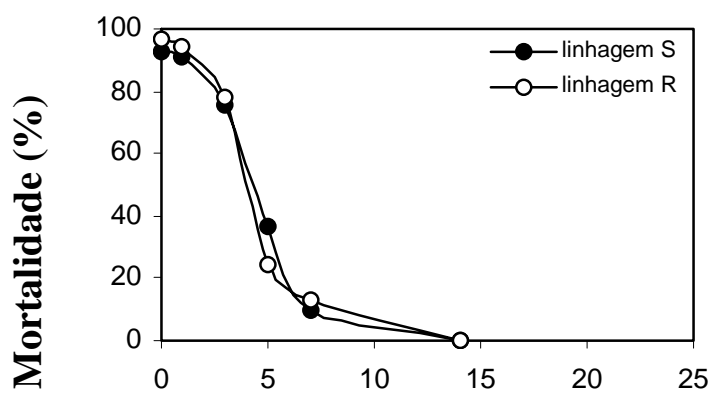

$120 \mathrm{~g}$ carbosulfam $+350 \mathrm{~g}$ endosulfam/ha

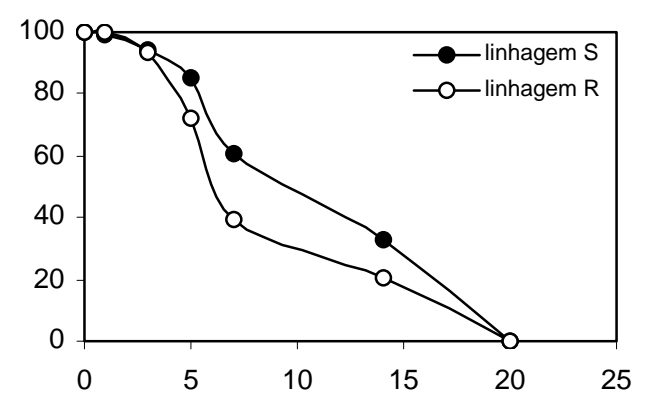

25 g tiametoxam/ha

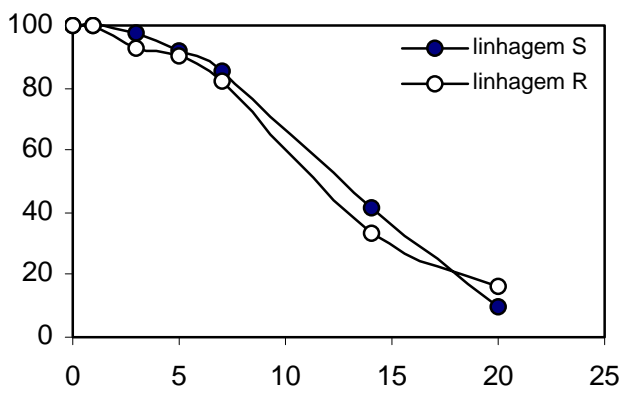

120 carbosulfam $+25 \mathrm{~g}$ tiametoxam/ha

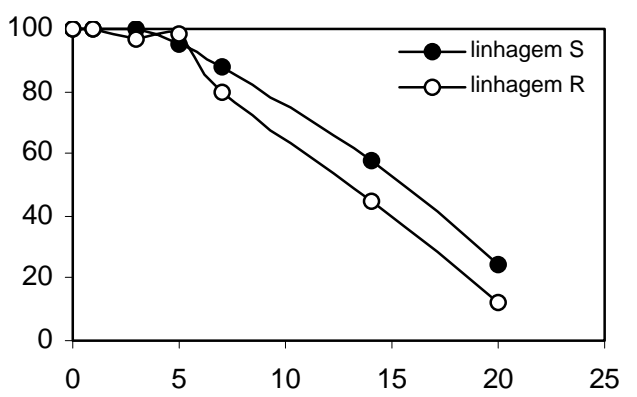

25 g tiametoxam $+350 \mathrm{~g}$ endosulfam/ha

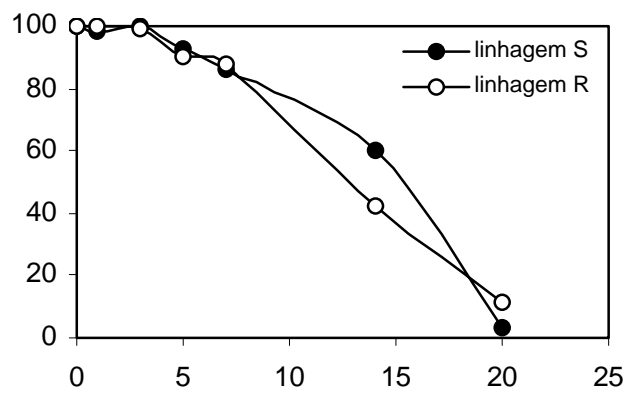

Idade do Resíduo (dias)

Figura 10- Mortalidade das linhagens de Aphis gossypii suscetível (S) e resistente (R) ao carbosulfam submetidas a diferentes idades de resíduos de inseticidas utilizados em mistura ou isoladamente 


\section{Considerações finais}

O cultivo de algodão no Brasil tem se destacado pela produção em larga escala, pelo uso de alta tecnologia e insumos nas grandes regiões produtoras, principalmente na região Centro-Oeste. Dessa forma, a cotonicultura brasileira tornou-se uma atividade econômica, onde as novas tecnologias desenvolvidas são prontamente adotadas pelos produtores. Como alguns exemplos temos o desenvolvimento do sistema de algodão safrinha (já adotado por alguns produtores) e do algodão geneticamente modificado (ainda não liberado para uso comercial). Essas novas tecnologias devem ser consideradas dentro de um programa de manejo da resistência de $A$. gossypii a inseticidas, uma vez que podem interferir no desenvolvimento da praga.

A safrinha de algodão, que é plantada no período de 10 de janeiro a 20 de fevereiro, possibilita que a cultura do algodão se estenda por mais dois meses. Essa sobreposição de cultivos poderá acarretar a migração de populações de pulgões de um cultivo de algodão na safra convencional para um cultivo de algodão safrinha, fazendo com que parte dos indivíduos sofram uma maior pressão de seleção a favor dos indivíduos resistentes.

Com a introdução do algodão geneticamente modificado que expressa algumas toxinas de Bacillus thuringiensis, será possível um controle mais eficiente de algumas pragas da ordem Lepidoptera. No entanto, devido à ausência de atividade de $B$. thuringiensis contra $A$. gossypii, mesmo com a introdução desta tecnologia, o controle químico de A gossypii baixa ainda será necessário. 
Outro fator importante é que a cultura do algodão apresenta um grande complexo de pragas (coleópteros, hemípteros, lepidópteros, tripes e ácaros) que necessita ser controlado, geralmente por meio de inseticidas. Dessa forma, os pulgões estão submetidos a constantes pressões de seleção não só com os inseticidas destinados ao seu controle, mas também com os inseticidas utilizados no controle de outras pragas.

No Brasil, pouco se sabe a respeito da evolução da resistência de $A$. gossypii a outros inseticidas. Assim, trabalhos que têm por objetivo a preservação da eficiência desses produtos passam a ser de extrema importância para o sucesso do controle dessa praga. Atenção especial deve ser dada também aos novos inseticidas como o diafentiurom e os do grupo dos neonicotinóides, pois o uso desses inseticidas tende a crescer em função da alta eficiência atingida no controle de A. gossypii e da seletividade aos inimigos naturais. Novos inseticidas como o flomicamida e pimetrozina que são fagodeterrentes, isto é eles bloqueiam o processo normal de alimentação dos afídeos, estão em fase de registro e logo estarão disponíveis aos produtores. Dessa forma, é imperiosa a realização de trabalhos de monitoramento da suscetibilidade em populações de A. gossypii a esses inseticidas, bem como em outros comumente utilizados, com o objetivo de evitar ou retardar a evolução da resistência a inseticidas. 


\section{CONCLUSÕES}

- Há diferenças significativas na suscetibilidade de populações de Aphis gossypii ao carbosulfam. Porém, não há diferenças significativas ao tiametoxam e endosulfam.

- A razão de resistência de Aphis gossypii ao inseticida carbosulfam é de 5,7 vezes.

- Há um aumento na frequiência de sobrevivência em populações de $A$. gossypii coletadas ao longo do ciclo da cultura.

- Não há resistência cruzada entre carbosulfam e os inseticidas tiametoxam e endosulfam.

- A resistência de A. gossypii ao carbosulfam é instável na ausência de pressão seletiva.

- Há custo adaptativo associado à resistência de A. gossypii ao carbosulfam.

- Não há vantagens na utilização da mistura de carbosulfam com tiametoxam ou endosulfam no manejo da resistência de A. gossypii ao carbosulfam. 


\section{REFERÊNCIAS BIBLIOGRÁFICAS}

ACHER, T.L.; BYNUM, E.D.; PLAPP JR, F.W. Chlorpyrifos resistance in greenbugs (Homoptera: Aphididae): cross-resistance and synergism. Journal of Economic Entomology, v.87, n. 6, p. 1437-1440, 1994.

BARBER, M.D.; MORAES G.D.; TATCHELL, G.M. Insecticide resistance in the currant-lettuce aphid, Nasonovia ribisnigri (Hemiptera: Aphididae) in the UK. Bulletin of Entomological Research, v.89, p.17-23, 1999.

BAUERNFEIND, R.J.; CHAPMAN, R.K. Nonstable parathion and endosulfan resistance in green peach aphids (Homoptera: Aphididae). Journal of Economic Entomology, v.78, n.3, p.516-522, 1985

BERANEK, A.P. Stable and non-stable resistance to dimethoate in the peachpotato aphid (Mizus persicae). Entomological Experimental \& Applied, v.17, p.381-390, 1974.

BLACKMAN, R.L. Reproduction, Cytogenetics and Development. In: MINKS, A.K.; HARREWIJN, P. (Ed.). Aphids: their biology, natural enemies and control. New York: Elsevier, 1987. p. 163-196. (Word Crop Pests, v.2A). 
BLACKMAN, R.L.; DEVONSHIRE, A.L.; SAWICKI, R.M. Co-inheritance of increased carboxyleterase activity and resistance to organophosphorus insecticides in Myzus persicae (Sulzer). Pesticide Science, v.8, p.163-166, 1977.

COSTA, J.T.N. Legislação do uso de defensivos: produção, comércio, armazenamento, transporte e fiscalização de produtos fitossanitários. In: CONGRESSO INTERNACIONAL DO AGRONEGÓCIO DO ALGODÃO; SEMINARIO ESTADUAL DA CULTURA DO ALGODÃO, 5: negócios e tecnologias para melhorar a vida., Cuiabá, 2000. Anais. Cuiabá: Fundação de Apoio à Pesquisa Agropecuária de Mato Grosso, 2000. p. 153-160.

CROFT, B.A. Developing a philosophy and program of pesticide resistance management. In: ROUSH, R.T.; TABASHNIK, B.E. (Ed.). Pesticide resistance in arthropods. New York: Chapman and Hall, 1990. p.277-296.

CROFT, B.A.; VAN DE BANN, H.E. Ecological and genetic factors influencing evolution of pesticide resistance in tetranychid and phytoseiid mites. Experimental \& Applied Acarology, v. 4, p.277-300, 1988.

DEGRANDE, P.E. Guia prático de controle das pragas do algodoeiro. Dourados: UFMS, 1998. 60p.

DEGRANDE, P.E. Manejo de pragas: realidade e desafios. In: CONGRESSO INTERNACIONAL DO AGRONEGÓCIO DO ALGODÃO; SEMINARIO ESTADUAL DA CULTURA DO ALGODÃO, 5: negócios e tecnologias para melhorar a vida., Cuiabá, 2000. Anais. Cuiabá: Fundação de Apoio à Pesquisa Agropecuária de Mato Grosso, 2000. p. 229-244. 
DELORME, R.; AUGÉ, D.; BÉTHENOD, M.T.; VILLATTE, F. Insecticide resistance in a strain of Aphis gossypii from southern France. Pesticide Science, v.49, p.90-96, 1997.

DENHOLM, I.; ROWLAND, M.W. Tactics for managing pesticide resistance in arthropods: theory and practice. Annual Review of Entomology, v.37, p.92-112, 1992.

DIXON, A.F.G. Parthenogenetic reproduction and the rate of increase in aphids. In: MINKS, A.K.; HARREWIJN, P. (Ed.). Aphids: their biology, natural enemies and control. New York: Elsevier, 1987. p. 269-287. (Word Crop Pests, v.2A).

EEGERS-SCHUMACHER, H.A. A comparison of the reproductive performance of insecticide-resistance and susceptible clones of Myzus persicae. Entomological Experimental \& Applied, v.34, p.301-307, 1983

FFRENCH-CONSTANT, R.H.; ROUSH, R.T. Resistance detection and documentation: the relative roles of pesticide and biochemical assays. In: ROUSH, R.T.; TABASHNIK, B.E. (Ed.). Pesticide resistance in arthropods. New York: Chapman and Hall, 1990. p.4-38

FNP CONSULTORIA \& COMÉRCIO. AGRIANUAL 2004: Anuário da agricultura brasileira. São Paulo, 2004. p.131-144: Algodão. 
FOSTER, S.P.; DENHOLM, A.L.; DEVONSHIRE, A.L. The ups and downs of insecticide resistance in peach-potato aphids (Myzus persicae) in the UK. Crop Protection, v.19, p.873-879, 2000.

FOSTER, S.P.; HARRINGTON, R.; DEWAT, A.M.; DENHOLM, I.; DEVONSHIRE, A.L. Temporal and spatial dynamics of insecticide resistance in Myzus persicae (Hemiptera; Aphididae). Pest Management Science, v.58, p.895-907, 2002

FOSTER, S.P.; HARRINGTON, R.; DEVONSHIRE, A.L.; DENHOLM, I.; CLARK, S.J.; MUGGLESTONE, M.A. Evidence for a possible fitness trade-off between insecticide resistance and the low temperature movement that is essential for survival of UK populations of Myzus persicae (Hemiptera: Aphididade). Bulletin of Entomological Research, v.87, p.573579, 1997.

FURK, C.; HINES, C.M. Aspects of insecticide resistance in the melon and cotton aphid, Aphis gossypii (Hemiptera: Aphididae). Annual Apply of Biology, v.123, p.9-17, 1983.

FURK, C.; POWELL, D.F.; HEYD, S. Pirimicarb resistance in the melon and cotton aphid, Aphis gossypii Glover. Plant Pathology, v.29, p.191-196, 1980.

GEORGHIOU, G.P. The evolution of resistance to pesticide. Annual Review of Ecology and Systematics, v.3, p.133-168, 1972. 
GEORGHIOU, G.P. Management of resistance in arthropods. In: GEORGHIOU,G.P.; SAITO, T. (Ed.). Pest resistance to pesticides. New York: Plenum, 1983. p.769-792.

GEORGHIOU, G.P.; TAYLOR. C.E. Genetics and biological influences in the evolution of insecticide resistance. Journal of Economic Entomology, v.70, n.3, p.319-323, 1977a.

GEORGHIOU, G.P.; TAYLOR. C.E. Operational influences in the evolution of insecticide resistance. Journal of Economic Entomology, v.70, n.5, p.653658, 1977b.

GEORGHIOU, G.P.; TEJEDA, A.L. The ocurrence of resistance to pesticides in arthropods. Rome: FAO, 1991. 318p.

GRAFTON-CARDWELL, E.E. Geographical and temporal variation in response to insecticides in various life stages of Aphis gossypii (Homoptera: Aphididae) infesting cotton in california. Journal of Economic Entomology, v.84, n.3, p.741-749, 1991.

GODFREY, L.D.; ROSENHEIM, J.A.; GOODELL, P.B. Cotton aphid emerges as major pest in SJV cotton. California Agriculture, v.54, n.6, p.26-29, 2000.

GUBRAN, E.E.; DELORME, R.; AUGÉ, D. Insecticide resistance in cotton aphid Aphis gossypii (Glov.) in the Sudan Guezira. Pesticide Science, v.35, p.101-107, 1992. 
GUILIN, C.; RUNZXI, L.; MINGJIANG, H. Comparasion of the cotton aphid resistance level between Xinjiang and Shandong populations. Resistance Pest Management, v.9, n.1, p.10-12, 1997.

HERRON, G.A.; POWIS, K.; ROPHAIL, J. Insecticide resistance in Aphis gossypii Glover (Hemiptera: Aphididae), a serious threat to Australian cotton. Australian Journal of Entomology, v.40, p.85-91, 2001.

HOLLINGSWORTH, R.G.; TABASHNIK, B.E.; ULLMAN, D.E.; JOHNSON, M.W.; MESSING, R. Resistance of Aphis gossypii (Homoptera: Aphididae) to insecticides in Hawaii: spatial patters and relation to insecticide use. Journal of Economic Entomology, v.87, n.2, p.293-300, 1994.

HOSKINS, W.M.; GORDON, H.T. Arthropod resistance to chemicals. Annual Review of Entomology, v.1, p.89-122, 1956

KERNS, D.L.; GAYLOR, M.J. Insecticide resistance in field populations of the cotton aphid (Homoptera: Aphididae). Journal of Economic Entomology, v.85, n.1, p.1-8, 1992.

LECLANT, F.; DEGUINE, J.P. Aphis (Hemptera: Aphididae). In: MATTHEWS, G.A.; TUNSTALL, J.P. (Ed.). Insect pests of cotton. UK: Cambridge, 1994. p.285-323.

LeOra Software. POLO-PC: a user's guide to Probit Or Logit analysis. LeOra Software, Berkeley, CA. 1987. 
NATIONAL RESEARCH COUNCIL. Prediction or resistance risk assessment. In: National Research Council, Pesticide resistance: strategies and tactics for management. Washington: National Academic Press, 1986. p. 271-278.

O’BRIEN, P.J.; ABDEL-AAL, Y.A.; OTTEA, J.A. et al. Relationship of insecticide resistance to carboxylesterases in Aphis gossypii (Homoptera: Aphididae) from Midsouth cotton. Journal of Economic Entomology, v.85, n.3, p.651-65, 1992.

PAPA, G. Situação atual e perspectivas futuras no manejo de resistência de pragas do algodoeiro a inseticidas. In: CONGRESSO BRASILEIRO DE ALGODÃO, 3., Dourados, 2001. Resumos das palestras. Campo Grande: Embrapa/UFMS, 2001. p. 46-50.

POZAROWSKA, B.J. Studies on low temperature survival, reproduction and development in Scottish clones of Myzus persica (Sultzer) and Aulacorthum solani (Kaltenbach) (Hemiptera: Aphididae)susceptible and resistance to organophosphates. Bulletin of Entomological Research, v.77, p.123-134, 1987.

ROBERT, Y. Aphids and their environment: dispersion and migration. In: MINKS, A.K.; HARREWIJN, P. (Ed.). Aphids: their biology, natural enemies and control. New York: Elsevier, 1987. p.299-313. (Word Crop Pests, v.2A).

ROBERTSON, J.L.; PREISLER, H.K. Pesticide bioassay with Arthropods. Boca Raton: CRC Press, 1992. 127 p. 
ROSOLEM, C.A. Ecofisiologia e manejo da cultura do algodoeiro. In: OMELLAS, A.P.; HIROMOTO, D.M.; YUYAMA, M.M.; CAMARGO, T.V. (Ed.). Boletin de Pesquisa de Algodão. Rondonópolis: Fundação MT, 2001. p.145-160.

ROUSH, R.T.; MILLER, G.L. Considerations for design of insecticide resistance monitoring programs. Journal of Economic Entomology, v.79, n.2, p.293298, 1986.

ROUSH, R.T.; McKENZIE, J.A. Ecological genetics of inseticide and acaricide resistance. Annual Review of Entomology, v. 32, n. 2, p. 361-380, 1987.

ROUSH, R.T.; DALY, J.C. The role of population genetics in resistance research and management. In: ROUSH, R.T. ; TABASHNIK, B.E. (Ed.). Pesticide resistance in arthropods. New York: Chapman and Hall, 1990. p. 97-152.

SANTOS, W.J. Manejo integrado de pragas do algodoeiro com destaque para as regiões de cerrado no Brasil. In: FUNDAÇÃO MATO GROSSO/EMBRAPA-ALGODÃO. Mato Grosso: liderança e competitividade. Rondonópolis: Fundação MT, 1999. 182p. (Boletim, 3).

SANTOS, W.J. Manejo de pragas na cultura do algodão no cerrado: histórico e perspectivas. In: CONGRESSO INTERNACIONAL DO AGRONEGÓCIO DO ALGODÃO; SEMINARIO ESTADUAL DA CULTURA DO ALGODÃO, 5: negócios e tecnologias para melhorar a vida., Cuiabá, 2000. Anais. Cuiabá: Fundação de Apoio à Pesquisa Agropecuária de Mato Grosso, 2000. p.161-170. 
SHUFRAN, R.A.; WILDE, G.E.; SLODERBECK, P.E. Response of tree greenbug (Homoptera: Aphididade) strains to five organophosphorous and two cabamate insecticides. Journal of Economic Entomology, v,90, n.2, p.283-286, 1997.

SILVEIRA NETO, S; NAKANO, O.; BARBIN, D.; VILLA NOVA, N.A. Manual de ecologia dos insetos. São Paulo: Ceres, 1976. 419p.

STONE, B.S.; SHUFRAN, R.A.; WILDE, G.E. Life history study of multiple clones of insecticide resistance and susceptible greenbug Schizaphis graminum (Homoptera:: Aphididae). Journal of Economic Entomology, v.93, n.3, p.971-974, 2000.

TAYLOR, C.E.; GEORGIOU, G.P. Influence of pesticide persistence in evolution of resistance. Environmental Entomology, v.11, n.3, p.746-750, 1982.

VENDRAMIM, J.D. Aspectos biológicos e avaliação de danos de Aphis gossypii Glover, 1877 (Homoptera-Aphididae) em Algodoeiro. Piracicaba, 1980, 121p. Dissertação (Mestrado) - Escola Superior de Agricultura "Luiz de Queiroz”, Universidade de São Paulo.

VENDRAMIM, J.D.; NAKANO, O. Avaliação de danos de Aphis gossypii Glover, 1977 (Homoptera: Aphididae) no algodoeiro cultivar 'IAC-17'. Anais da Sociedade Entomológica do Brasil, v.10, n. 1, p.89-96, 1981. 
WANG, K.Y.; LIU, T.X.; YU,C.H.; JIANG, X.Y.; YI, M.Q. Resistance of Aphis gossypii to fenvalerate and imidacloprid and activities of detoxification enzymes on cotton an cucumber. Journal of Economic Entomology, v.95, n.2, p.407-413, 2002

WHALON, M.; MOTA SANCHES, M.; DUYNSLAGER, L. The data base of arthropods resistance to pesticide. Michigan State University - Center for Plant Systms. (23 dec. 2004). 
APÊNDICE 
APÊNDICE 1. Tabela de vida e fertilidade da linhagem de Aphis gossypii suscetível ao inseticida carbosulfam.

\begin{tabular}{|c|c|c|c|c|c|}
\hline Fase & $\mathbf{X}$ & $\mathbf{m x}$ & $\mathbf{l x}$ & mx.lx & mx.Ix.X \\
\hline Ninfa I & - & - & 1 & - & - \\
\hline Ninfa II & - & - & 1 & - & - \\
\hline Ninfa III & - & - & 1 & - & - \\
\hline Ninfa V & - & - & 1 & - & - \\
\hline \multirow[t]{19}{*}{ Adulta } & 6,5 & 0,22 & 1,00 & 0,22 & 1,44 \\
\hline & 7,5 & 1,89 & 1,00 & 1,89 & 14,17 \\
\hline & 8,5 & 2,37 & 1,00 & 2,37 & 20,15 \\
\hline & 9,5 & 3,04 & 1,00 & 3,04 & 28,85 \\
\hline & 10,5 & 3,00 & 1,00 & 3,00 & 31,50 \\
\hline & 11,5 & 3,11 & 1,00 & 3,11 & 35,78 \\
\hline & 12,5 & 3,22 & 1,00 & 3,22 & 40,28 \\
\hline & 13,5 & 3,00 & 1,00 & 3,00 & 40,50 \\
\hline & 14,5 & 3,15 & 1,00 & 3,15 & 45,73 \\
\hline & 15,5 & 3,50 & 1,00 & 3,50 & 54,25 \\
\hline & 16,5 & 2,85 & 1,00 & 2,85 & 46,96 \\
\hline & 17,5 & 3,23 & 1,00 & 3,23 & 56,54 \\
\hline & 18,5 & 2,72 & 0,92 & 2,51 & 46,37 \\
\hline & 19,5 & 2,58 & 0,92 & 2,38 & 46,34 \\
\hline & 20,5 & 2,34 & 0,92 & 2,15 & 44,05 \\
\hline & 21,5 & 2,03 & 0,85 & 1,72 & 37,04 \\
\hline & 22,5 & 1,37 & 0,81 & 1,11 & 24,98 \\
\hline & 23,5 & 0,72 & 0,69 & 0,49 & 11,62 \\
\hline & 24,5 & 0,35 & 0,46 & 0,16 & 3,99 \\
\hline
\end{tabular}


APÊNDICE 1. Tabela de vida e fertilidade da linhagem de Aphis gossypii suscetível ao inseticida carbosulfam.

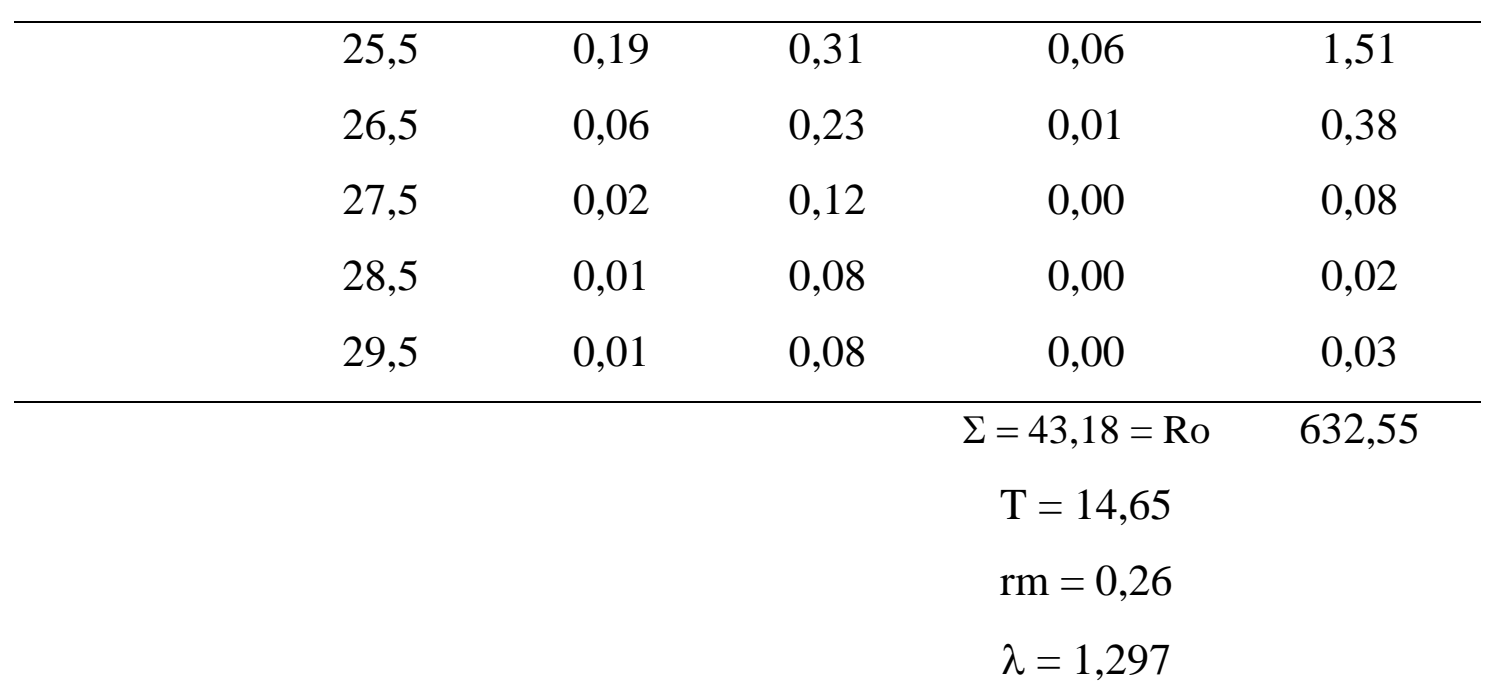


APÊNDICE 2. Tabela de vida e fertilidade da linhagem de Aphis gossypii resistente ao inseticida carbosulfam.

\begin{tabular}{|c|c|c|c|c|c|}
\hline Fase & $\mathbf{x}$ & $\mathbf{m x}$ & $\mathbf{L x}$ & mx.lx & mx.lx.x \\
\hline Ninfa I & - & - & 1 & - & - \\
\hline Ninfa II & - & - & 1 & - & - \\
\hline Ninfa III & - & - & 1 & - & - \\
\hline Ninfa V & - & - & 1 & - & - \\
\hline \multirow[t]{20}{*}{ Adulta } & 6,5 & 0,52 & 1,00 & 0,52 & 3,38 \\
\hline & 7,5 & 0,81 & 1,00 & 0,81 & 6,08 \\
\hline & 8,5 & 1,33 & 1,00 & 1,33 & 11,31 \\
\hline & 9,5 & 1,33 & 1,00 & 1,33 & 12,64 \\
\hline & 10,5 & 1,41 & 1,00 & 1,41 & 14,81 \\
\hline & 11,5 & 1,63 & 1,00 & 1,63 & 18,75 \\
\hline & 12,5 & 1,63 & 1,00 & 1,63 & 20,38 \\
\hline & 13,5 & 1,52 & 1,00 & 1,52 & 20,52 \\
\hline & 14,5 & 1,24 & 0,93 & 1,15 & 16,72 \\
\hline & 15,5 & 1,53 & 0,70 & 1,07 & 16,60 \\
\hline & 16,5 & 1,55 & 0,41 & 0,64 & 10,49 \\
\hline & 17,5 & 1,83 & 0,22 & 0,40 & 7,05 \\
\hline & 18,5 & 1,60 & 0,19 & 0,30 & 5,60 \\
\hline & 19,5 & 1,25 & 0,15 & 0,19 & 3,66 \\
\hline & 20,5 & 1,00 & 0,07 & 0,07 & 1,52 \\
\hline & 21,5 & 1,00 & 0,04 & 0,04 & 0,86 \\
\hline & & & & $\Sigma=14,04=$ Ro & 170,27 \\
\hline & & & & $\mathrm{T}=12,13$ & \\
\hline & & & & $\mathrm{rm}=0,22$ & \\
\hline & & & & $\lambda=1,246$ & \\
\hline
\end{tabular}

